\title{
Factors affecting chlorophyll a concentration in the central Beibu Gulf, South China Sea
}

\author{
Andrea Bauer, Joanna J. Waniek* \\ Leibniz Institute for Baltic Sea Research Warnemünde, Department of Marine Chemistry, 18119 Rostock, Germany
}

\begin{abstract}
Since in situ data are sparse, we used a 1D coupled physical-biological model to investigate the complex connection between atmospheric forcing, associated physical water column structure, and primary production within the entire seasonal cycle in the central Beibu Gulf from 2000 to 2010. The results were corroborated by remotely measured sea surface temperature (SST) and surface chlorophyll concentrations in combination with in situ measurements (temperature and chlorophyll) carried out during 2 German-Chinese cruises (September/October 2009 and December 2011). Over the $11 \mathrm{yr}$ period, 87\% of the observed variance in daily SST was captured by the model. The model indicates that the central Beibu Gulf is generally unaffected by water masses from the South China Sea and the Beibu Gulf coastal regions. Thus, most of the primary production is locally generated. A strong stratification and a deep chlorophyll maximum develop during summer, vanishing in autumn when the stratification breaks down due to the change from the weak southwest to the stronger northeast monsoon. Deep mixing brings a higher nutrient supply to the surface waters, leading to a phytoplankton bloom which lasts on average about 6 mo. Along with the semi-annual wind system change, temporally short, strong wind events affect primary productivity in the region. Typhoon crossings can enhance primary production by up to $275 \%$ relative to the summer background chlorophyll concentration at the surface according to our modeling results. These events play an important role in primary production and the corresponding biogeochemical cycling in this oligotrophic region during the summer and the autumn low-productive periods.
\end{abstract}

KEY WORDS: Phytoplankton bloom - Model · Shelf sea · Typhoon - Tidal forcing · Remote sensing $\cdot$ Gulf of Tonkin

Resale or republication not permitted without written consent of the publisher

\section{INTRODUCTION}

Primary production and the associated energy transfer into higher trophic levels due to grazing (Ross 2004), as well as nutrient recycling through biomass sinking and decomposition play a major role in the biogeochemical cycling of oceanic regions (Chen et al. 2003). For this, phytoplankton is fundamentally important for the functioning of marine ecosystems (e.g. Waniek \& Holliday 2006) and crucial for oceanic carbon fixation, which in turn has an impact on the atmospheric carbon dioxide content (Chen et al. 2003).
The growth of phytoplankton depends on the availability of nutrients, incident solar irradiance, and grazing pressure and varies regionally through different oceanic conditions (Yoder et al. 1993). Compared to land-based primary producers, phytoplankton are subject to the strong variability of the turbulent marine environment. This means that their occurrence, regional distributions, and seasonal cycles are determined by physical processes (Ward \& Waniek 2007) such as currents, vertical mixing, particularly through tides generating a near-bottom turbulence and wind-stress creating additional turbulence near the sea surface (Tett et al. 1986), and 
stratification. As a result, phytoplankton always have to cope with rapid vertical attenuation of light (Sharples 1999) and the limitation of nutrient supply from the deeper waters in stratified regimes.

Tides, wind, solar radiation, and their interactions affect motion and mixing of the water column (Dickey 1988) and lead to the characteristic seasonal cycles in the mixed layer thickness (Williams \& Follows 2003). From autumn to spring (in the northern hemisphere), low surface heating and a steady influence of wind and tides lead to erosion of the seasonal thermocline and hence to a deep mixing. Depending on the water depth, this mixing can even reach the bottom, which is common in shallow shelf regions. The deep mixing leads to a high nutrient supply in the euphotic zone, which could immediately trigger a phytoplankton bloom. This has been identified as the determinant of the primary production in, for instance, the western part of the Mediterranean Sea (Klein \& Coste 1984). It is the availability of light which makes the difference in the timing of the phytoplankton bloom between regions in high versus in low latitudes. Seasonal cycles in subtropical waters show highest surface chlorophyll concentrations during winter, e.g. in the South China Sea (e.g. Liu et al. 2002), and lowest in summer, in contrast to polar/subpolar and temperate waters (Howard \& Yoder 1997), which are dominated by a spring bloom (Yoder et al. 1993), e.g. the Northeast Atlantic (Waniek 2003). Furthermore, depending on the depth of the oceanic region, phytoplankton may be vertically transported below the euphotic depth, due to the deep mixing and tidally-driven turbulence, and can no longer conduct photosynthesis (Lauria et al. 1999, e.g. North Atlantic, cf. Ward \& Waniek 2007). If the influence of solar irradiance overcomes the capacity for tidal mixing in deep regions or regions with low tidal currents, the vertically homogeneous water column can no longer be maintained and thermally stratifies in spring and summer (Sharples 2008). Algal cells and nutrients are then trapped in the surface layer and may induce a spring phytoplankton bloom.

As an important physical barrier, the seasonal thermocline separates the wind-mixed surface layer from tidally-mixed deeper waters (Ross \& Sharples 2007) and inhibits the transfer of properties, such as nutrients, algal cells, and oxygen (e.g. Klein \& Coste 1984, Sharples et al. 2001). Many regions show oligotrophic conditions during the period of vertical stratification (Varela et al. 1992) due to the fast consumption of nutrients in the surface layer and the thermocline, which prevents nutrient replenishment from the bottom layer. In those regions, a deep chlorophyll maximum (DCM), which in most studies represents a real maximum in phytoplankton biomass (Sharples et al. 2001), is commonly observed within the thermocline. The establishment of the DCM is caused by unsteady pulses of mixing processes which may bring nutrients into the thermocline (Klein \& Coste 1984, Sharples \& Tett 1994), such as periodical tidally-driven turbulence, surface breaking waves, wind events, and internal wave instabilities (Lauria et al. 1999). These pulses lead to an oscillation of the thermocline supporting a nutrient flux into the surface layer. Due to episodic weakening of the thermocline and consequent nutrient input to the surface waters, the variability in the surface wind stress, especially during storm events such as typhoons, also contributes to the formation of the subsurface chlorophyll maximum (Klein \& Coste 1984, Sharples \& Tett 1994) and is important especially in the subtropical/tropical regions.

To understand the temporal and spatial variability of primary production in marine environments, the connection between primary production and seasonal variability of the vertical water column stability (Sharples 1999, Ross 2006) needs to be investigated. The timing, strength, and duration of the phytoplankton bloom is known to play a fundamental role for growth and survival of organisms of higher trophic levels and hence the functioning of biological communities (e.g. Ridderinkhof 1992, Waniek \& Holliday 2006, Sharples 2008). For the northeast Atlantic, meteorological factors (solar heating, wind mixing) have been shown to be responsible for timing and strength of the spring bloom (Waniek 2003).

To investigate the complex connection between atmospheric forcing, associated physical water column structure, and primary production, continuous and extensive sampling within the respective study area is necessary. In most regions this is impossible, although we can use numerical models as tools to explain intermittently observed distributions.

The first aim of this study was therefore to examine the timing of stratification and phytoplankton growth in the Beibu Gulf throughout an annual cycle using a simple 1D model. Due to a lack of empirical in situ data, little is known about the oceanic and biological processes, including spatial and seasonal variation of phytoplankton concentration, in this region (Tang et al. 2003), which plays an important role in biogeochemical cycling in the northwestern region of the South China Sea (Song 2010). The modeling results were compared to satellite as well as in situ measurements and literature values from all seasons in different years. Since the Beibu Gulf is affected by tidal 
currents with velocities up to $0.6 \mathrm{~m} \mathrm{~s}^{-1}$ (Manh \& Yanagi 1997) and occasional typhoon crossings, 2 other questions arise: (1) What effect does the spring-neap tidal cycle have on primary production in the Beibu Gulf, especially within the thermocline in relation to the deep chlorophyll maximum, and (2) to what extent do strong wind events $\left(>10 \mathrm{~m} \mathrm{~s}^{-1}\right.$ ) affect phytoplankton growth? Both forces can contribute to the enhancement of nutrient flux from the deeper into the surface water layers, which in turn can cause the development of a phytoplankton bloom (Williams \& Follows 2003). The final question is: Which factors are important in generating interannual variability in the timing of stratification and the phytoplankton bloom?

\section{MATERIALS AND METHODS}

\section{Study area}

The Beibu Gulf, also known as the Gulf of Tonkin, is a hydrodynamically variable region influenced by the Asian monsoon system, tidal currents, and occasional typhoon activity. It is a marginal sea of the South China Sea located within the broad Sunda-

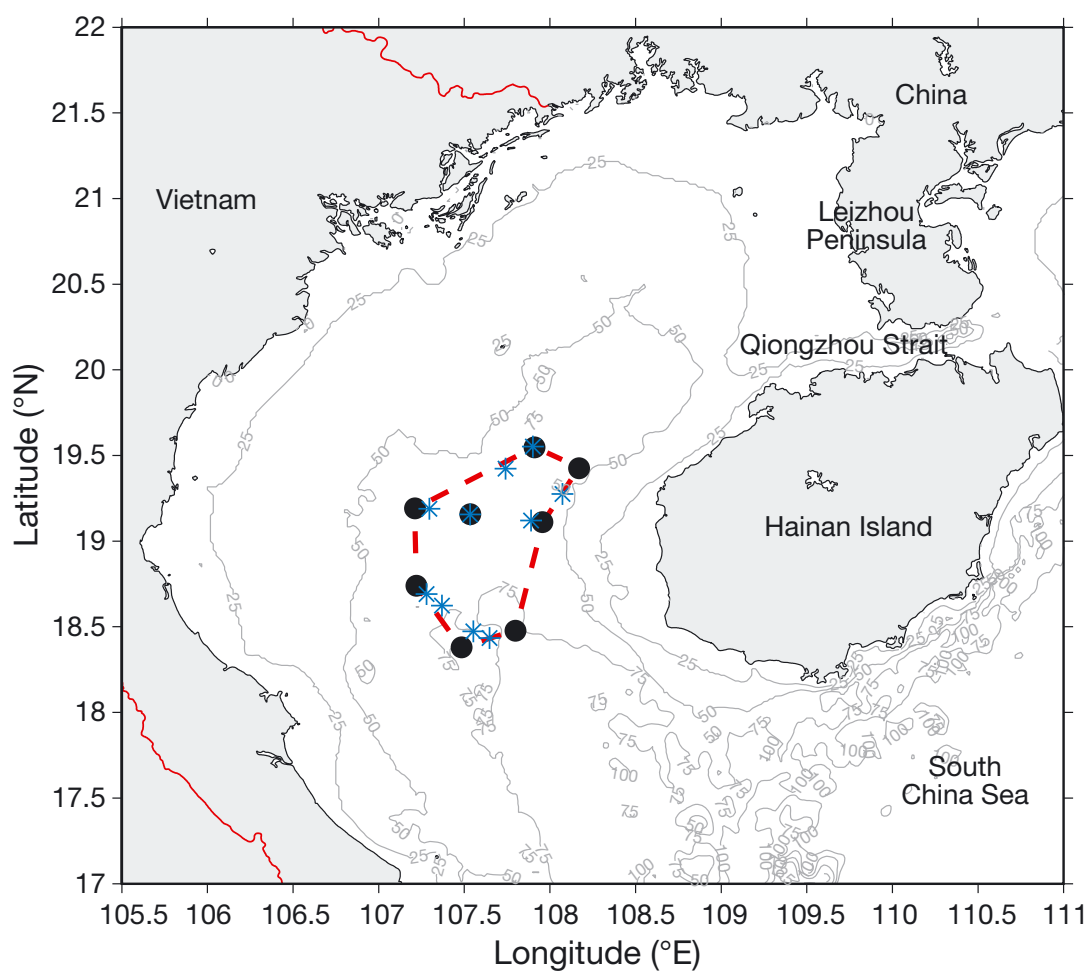

Fig. 1. Study area in the eastern Beibu Gulf. Filled circles indicate sampling stations of the FENDOU 5 cruise in September/October 2009 and the central Beibu Gulf (dashed red line). Blue stars indicate the sampling stations of the SONNE cruise in December 2011
Arafura Shelves Province (Longhurst 1998). The region is characterized by a large riverine discharge in the north and northwest, a broad opening in the south connecting the gulf with the South China Sea, and the Qiongzhou Strait, a narrow opening to the South China coastal area in the northeast. A year-round westward mean water transport through the Qiongzhou Strait forces a gulf-wide cyclonic circulation pattern in all seasons (Shi et al. 2002, Wu et al. 2008).

In this study, we concentrated on the central Beibu Gulf (Fig. 1), a region which may only be affected by external water masses to a small degree in comparison to other regions within the gulf (Bauer et al. 2013). Therefore, most of the primary production should be locally generated, with a small amount being transported through Qiongzhou Strait or from the South China Sea during strong wind events.

The central Beibu Gulf is an area with a depth between 54 and $78 \mathrm{~m}$ and a summer stratification with a strong thermocline between 20 and $50 \mathrm{~m}$ depth (Huang et al. 2008, Bauer et al. 2013). Surface chlorophyll a (chl a) concentrations are low in summer $\left(<0.5 \mathrm{mg} \mathrm{m}^{-3}\right)$ and show a seasonal peak in winter due to the strong northeast monsoonal winds (Hu et al. 2003, Tang et al. 2003). Typically for oligotrophic regions, only low surface nitrate (up to $0.5 \mu \mathrm{M}$ ) and phosphate (at detection limit) concentrations were found in the central Beibu Gulf with an N:P ratio $>16$ indicating phosphate limitation (Bauer et al. 2013). Due to the strong stratification in summer, nutrient supply from the deeper nutrient-rich water is limited, and enhanced chlorophyll concentrations are located in the vicinity of the thermocline, where sufficient nutrient concentrations and light are available. This deep chlorophyll maximum lies typically in around 30 to $50 \mathrm{~m}$ depth with a maximum chl a concentration of about 0.6 to $1 \mathrm{mg} \mathrm{m}^{-3}$ (Huang et al. 2008, Wu 2008, Bauer et al. 2013).

\section{In situ data for model validation}

Observational data were collected during the German-Chinese FENDOU 5 cruise in September/October 2009 and the SONNE 219 cruise in December 2011. Using an IOW (Institut für Ostseeforschung Warnemünde) mini PUMP CTD system (Strady et al. 2008), 
depth profiles of hydrographical parameters (temperature, conductivity, oxygen) were recorded at 8 stations within the central Beibu Gulf during the FENDOU 5 cruise. For hydrographic profiling and water sampling, a Seabird CTD was used during the SONNE 219 cruise. Water samples were taken at different depths during the upcast for chlorophyll and nutrient analysis $\left(\mathrm{NO}_{2}, \mathrm{NO}_{3}, \mathrm{PO}_{4}, \mathrm{SiO}_{4}\right)$. The samples were low vacuum filtered through $0.7 \mu \mathrm{m}$ Whatman GF/F glass fiber filters, which were pre-combusted for preparing water samples for nutrient analysis, and frozen at around $-20^{\circ} \mathrm{C}$. Extracted chlorophyll samples (IOC-SCOR 1994) were analyzed fluorometrically (Turner 10-AU) without correction for phaeopigments. We used an autoanalyzer (Evolution III, Aliance Instruments) to process nutrient samples (detection limits: $\mathrm{NO}_{2}: 0.02 \mu \mathrm{M}_{i} \mathrm{NO}_{3}: 0.05 \mu \mathrm{M}_{i} \mathrm{PO}_{4}$ : $0.02 \mu \mathrm{M}_{i} \mathrm{SiO}_{4}: 0.1 \mu \mathrm{M}$ ) following standard methods (Hansen \& Koroleff 1999).

Furthermore, in situ CTD data (temperature) and surface chlorophyll concentrations from August 2009, August 2010, and September 2011 provided by the South China Sea Branch of the State Oceanic Administration (SOA) and from the World Ocean Circulation Experiment (WOCE) Upper Ocean Thermal (WOCE UOT 2006, available at http://doi.pangaea. de/10.1594/PANGAEA.361180?format=html) from January 1992 were used for model validation.

\section{Simple 1D coupled physical-biological model}

To investigate the link between the physical environment, especially stratification and mixing of the water column, and phytoplankton growth in the central Beibu Gulf, a simple 1D coupled physicalbiological model established by Sharples (1999) was used. This model is limited to depths less than $200 \mathrm{~m}$ and can be applied to regions from estuaries to the shelf edge (Sharples 1999). The physical module of the model simulates daily mean vertical profiles of temperature $\left({ }^{\circ} \mathrm{C}\right.$ ), $u$-component of currents (zonal, $\left.\mathrm{m} \mathrm{s}^{-1}\right)$, and turbulent mixing $\left(\mathrm{m}^{2} \mathrm{~s}^{-1}\right)$ with $1 \mathrm{~m}$ depth resolution. An oscillating sea surface slope, with 2 tidal constituents, drives the tidal currents. Only the $\mathrm{M}_{2}$ and $\mathrm{S}_{2}$ tidal constituents are used because these are mainly responsible for the spring-neap tidal cycle (Sharples 2008). This allows investigation into the effect of varying kinetic energy levels in the bottom layer caused by the strongest and weakest tidal currents for a semimonthly time period. Meteorological data, daily mean wind $u$ - and $v$-components (zonal and meridional, $\mathrm{m} \mathrm{s}^{-1}$ ), daily mean dewpoint temper- ature $\left({ }^{\circ} \mathrm{C}\right)$, and daily mean solar irradiance $\left(\mathrm{W} \mathrm{m}^{-2}\right)$, are used by the physical module to calculate heat fluxes across the air-sea boundary and wind-driven momentum flux transmitted into the water column by using a quadratic stress boundary condition at the sea surface (Sharples 1999). The daily mean vertical profiles of the photosynthetically active radiation (PAR, $\mathrm{W} \mathrm{m}^{-2}$ ) are calculated by the model, determining the surface PAR as a fraction of the incident solar radiation (Table 1). PAR is then distributed through the water column by using a vertical absorption coefficient (Table 1; Sharples 1999). As the attenuation coefficient for PAR changes seasonally within each region, it was calculated after Kirk (2011) by using the mean Secchi depth of $9.2 \mathrm{~m}$ determined from all, only sparsely available, Secchi depths measured from the FENDOU 5 and SONNE cruises.

The biological component of the model is a simple cell quota, threshold-limitation scheme after Tett et al. (1986), simulating vertical profiles of phytoplankton biomass (in $\mathrm{mg} \mathrm{chl} \mathrm{m}^{-3}$ ) and dissolved inorganic nitrogen (DIN, in $\mathrm{mmol} \mathrm{m}^{-3}$ ). This module has the same vertical $(1 \mathrm{~m})$ and temporal (daily) resolution as the physical component. Phytoplankton growth depends on the availability of light, driven by the mean PAR within a model grid depth element (Sharples 1999), and DIN. Both potentially limiting resources lead to respiration if there is insufficient growth due to the light environment or nutrient limitation (Sharples et al. 2006). A fixed grazing rate that recycles nutrients acts on phytoplankton biomass throughout the year, and in addition, remineralized nitrogen diffuses from the seabed. To simulate the behavior of zooplankton feeding when it is energetically favorable, the assumed linear grazing (Table 1; grazing exponent) is only allowed to take place if the biomass is greater than a threshold value (Sharples \& Tett 1994). This

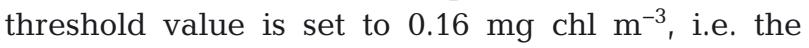
lowest remotely measured surface chlorophyll concentration for the central Beibu Gulf in 2009. Phytoplankton biomass and DIN are vertically mixed by turbulence calculated by the physical module. Initialization parameters used for both modules (physical and biological) are summarized in Table 1.

The maximum depth of the central Beibu Gulf averages $63 \mathrm{~m}$; this depth was chosen as well as the mean latitude of $19^{\circ} \mathrm{N}$. Current data were only obtained during the spring tide, leading to a calculated mean $\mathrm{M}_{2}$ amplitude of $0.6 \mathrm{~m} \mathrm{~s}^{-1}$. For the neap tide, a lowering of this amplitude is expected, which would lead to a lower mean $\mathrm{M}_{2}$ amplitude. Therefore, for all model runs, the $\mathrm{M}_{2}$ amplitude was set to the mean value of $0.15 \mathrm{~m} \mathrm{~s}^{-1}$, containing several tidal cycles, estimated 
Table 1. Initialization parameters for the model runs used in the physical and biological module of the model. Chl: chlorophyll; PAR: photosynthetically active radiation; DIN: dissolved inorganic nitrogen; SST: sea surface temperature

\begin{tabular}{|c|c|c|}
\hline Parameter (unit) & Value & Source \\
\hline \multicolumn{3}{|l|}{ Physical module } \\
\hline Depth $(\mathrm{m})$ & 63 & \\
\hline Maximum eddy viscosity and diffusivity $\left(\mathrm{m}^{2} \mathrm{~s}^{-1}\right)$ & 0.1 & Sharples (1999) \\
\hline Bottom quadratic drag coefficient & $3.0 \times 10^{-3}$ & Sharples (1999) \\
\hline Latitude $\left({ }^{\circ} \mathrm{N}\right)$ & 19 & \\
\hline Background viscosity and diffusivity $\left(\mathrm{m}^{2} \mathrm{~s}^{-1}\right)$ & $1.0 \times 10^{-5}$ & Sharples (1999) \\
\hline Amplitude of $\mathrm{M}_{2}$ tidal current $\left(\mathrm{m} \mathrm{s}^{-1}\right)$ & 0.15 & $\begin{array}{l}\text { Zu et al. (2008), Manh \& } \\
\text { Yanagi (1997) }\end{array}$ \\
\hline $\mathrm{S}_{2}$ tidal amplitude (as fraction of $\mathrm{M}_{2}$ ) & 0.98 & Present study \\
\hline Light attenuation coefficient $\left(\mathrm{m}^{-1}\right)$ & 0.1 & Kirk (2011) \\
\hline Heat shading coefficient $\left(\mathrm{m}^{2}[\mathrm{mg} \mathrm{chl}]^{-1}\right)$ & 0.012 & Sharples (1999) \\
\hline Initial homogeneous temperature $\left({ }^{\circ} \mathrm{C}\right)$ & 24.41 & Satellite SST \\
\hline Fraction of solar radiation that is PAR & 0.45 & Sharples (1999) \\
\hline Attenuation coefficient for PAR $\left(\mathrm{m}^{-1}\right)$ & 0.15 & Present study \\
\hline Pigment absorption cross section $\left(\mathrm{m}^{2}[\mathrm{mg} \mathrm{chl}]^{-1}\right)$ & 0.012 & Sharples (1999) \\
\hline Maximum near bed DIN concentration $\left(\mathrm{mmol} \mathrm{m}^{-3}\right)$ & 2.12 & Present study \\
\hline Benthic nutrient input rate $\left(\mathrm{s}^{-1}\right)$ & $2.3 \times 10^{-7}$ & Sharples (1999) \\
\hline \multicolumn{3}{|l|}{ Biological module } \\
\hline Subsistence quota (mmol N [mg chl] $]^{-1}$ ) & 0.2 & Sharples (1999) \\
\hline Maximum quantum yield (mg C $[\mathrm{mg} \mathrm{chl}]^{-1} \mathrm{~d}^{-1}\left[\mathrm{~W} \mathrm{~m} \mathrm{~m}^{-2}\right]^{-1}$ ) & 4.1 & Sharples (1999) \\
\hline Cell chl:carbon ratio $\left(\mathrm{mg}\right.$ chl $\left.[\mathrm{mg} \mathrm{C}]^{-1}\right)$ & 0.02 & Sharples (1999) \\
\hline Maximum cell quota (mmol N [mg chl $]^{-1}$ ) & 1.0 & Sharples (1999) \\
\hline Recycled proportion of grazed nutrients & 0.5 & $\begin{array}{l}\text { e.g. Tett (1981), Sharples } \\
\text { (1999), Ross \& } \\
\text { Sharples (2008) }\end{array}$ \\
\hline Maximum specific growth rate $\left(\mathrm{d}^{-1}\right)$ & 1.2 & Sharples (1999) \\
\hline Maximum nutrient uptake rate $\left(\mathrm{mmol}\right.$ DIN $\left.[\mathrm{mg} \mathrm{chl}]^{-1} \mathrm{~d}^{-1}\right)$ & 2.0 & Sharples (1999) \\
\hline Nutrient concentration for half maximum uptake (mmol DIN m${ }^{-3}$ ) & 0.5 & $\begin{array}{l}\text { e.g. Waniek (2003), Sharples } \\
\text { et al. (2006), Waniek } \\
\text { \& Holliday (2006) }\end{array}$ \\
\hline Grazing threshold limit (mg $\mathrm{chl} \mathrm{m}^{-3}$ ) & 0.16 & Present study \\
\hline Respiration rate $\left(\mathrm{mg} \mathrm{C}[\mathrm{mg} \mathrm{chl}]^{-1} \mathrm{~d}^{-1}\right)$ & 3.5 & Sharples (1999) \\
\hline Grazing rate (fraction standing stock $\mathrm{d}^{-1}$ ) & 0.12 & $\begin{array}{l}\text { e.g. Sharples \& Tett (1994), } \\
\text { Sharples (1999), Sharples } \\
\text { et al. (2006) }\end{array}$ \\
\hline Grazing exponent & 1.0 & Sharples (1999) \\
\hline Limiting nitrate concentration (mmol DIN m ${ }^{-3}$ ) & 0.32 & Present study \\
\hline
\end{tabular}

from Manh \& Yanagi (1997) as well as Zu et al. (2008) for the central Beibu Gulf. Published tidal ellipse polarizations for the Beibu Gulf are conflicting (e.g. Manh \& Yanagi 1997, Zu et al. 2008). For this reason, the tidal cycles recorded during the FENDOU 5 cruise at different depths were used to define the tidal ellipse polarization as a degenerated one. The mean $\mathrm{S}_{2}$ tidal amplitude (0.98) which is expressed as a fraction of $\mathrm{M}_{2}$, was calculated from the predictions provided by harmonic analysis for the current records (Emery \& Thomson 2001). Changing the mean $\mathrm{S}_{2}$ tidal amplitude did not show any significant effect in the model output. As a result of the $\mathrm{S}_{2}$ tidal amplitude activation from 0 to 1 , a cooling of about $0.2 \%$ in the upper $49 \mathrm{~m}$ of the water column and a warming of about $0.9 \%$ in the bottom waters was produced.
The initial homogeneous temperature was taken from remotely measured sea surface temperature (SST; see subsection 'Meteorological and comparative satellite data') on 31 December from the previous year, taking into account that the central Beibu Gulf is well-mixed in winter (Table 2). The maximum near bed DIN concentration was estimated from the zonally averaged bottom nitrate concentrations measured during the FENDOU 5 cruise. The parameters in the initial phytoplankton file describe a simple, neutrally buoyant phytoplankton species (Sharples 1999). Within the model, only DIN was used as a nutrient, but based on our measurements, the Beibu Gulf seems to be phosphate limited (Bauer et al. 2013). In general, phytoplankton assimilates phosphate whenever available and accumulates it within 


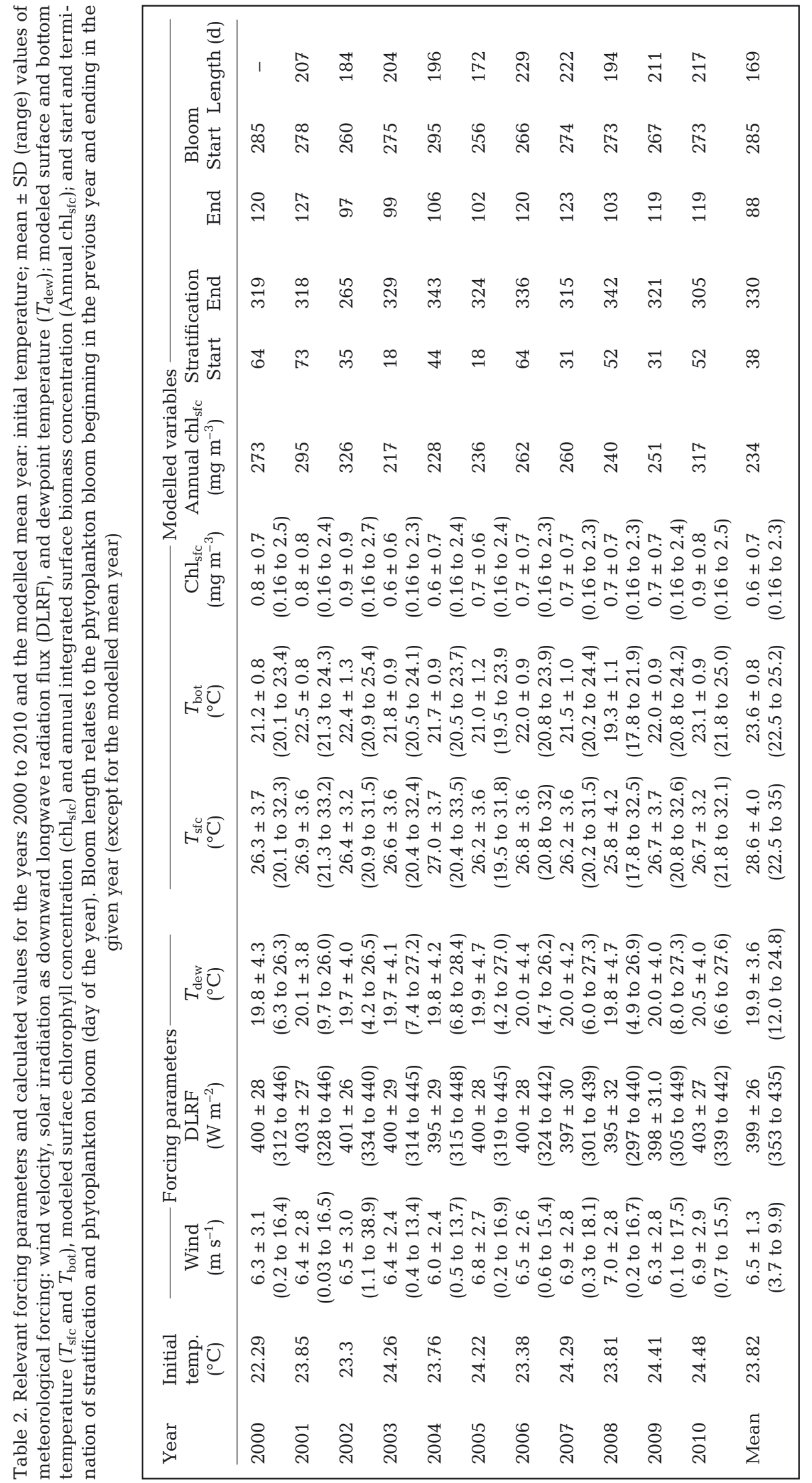

the cells, allowing ongoing growing during poor living conditions (M. Nausch pers. comm.). To include non-modeled phosphate, the phosphate detection limit of $0.02 \mu \mathrm{M}$ was used to calculate the corresponding nitrate concentration using the Redfield ratio. The calculated limiting nitrate concentration of $0.32 \mathrm{mmol} \mathrm{DIN} \mathrm{m}^{-3}$ is equivalent to the $0.3 \mathrm{mmol} \mathrm{DIN} \mathrm{m}^{-3}$ external concentration at which phytoplankton is generally capable to actively take up DIN (Reynolds 2006).

\section{Meteorological and comparative satellite data}

The model was forced with daily surface $u$ - and $v$-components of wind, dewpoint temperature, calculated after Wanielista et al. (1997) using air temperature and relative humidity, and downward longwave radiation flux all taken from the National Center for Environmental Prediction (NCEP) obtained at www.esrl.noaa.gov for 11 yr (2000 to 2010; Fig. 2, see also Fig. S1 in the supplement at www. int-res.com/articles/suppl/m474 p067_supp.pdf). As the spatial resolution of the NCEP reanalysis data set is $2.5^{\circ} \times 2.5^{\circ}$ (Kalnay et al. 1996), the Beibu Gulf area has been cubically interpolated to a resolution of $0.1^{\circ} \times 0.1^{\circ}$. The interpolated meteorological data were averaged for the entire area in the central Beibu Gulf to force the model $\left(18.3-19.6^{\circ} \mathrm{N}, 107.2-108.2^{\circ} \mathrm{E}\right.$; Fig. 1).

Comparative satellite data for daily SST were taken from www. remss.com (Tropical Rainfall Measuring Mission Microwave Imager, resolution $0.25^{\circ} \times 0.25^{\circ}$ ) and used for the comparison with the predicted SST. To compare the modeled primary production, monthly SeaWiFS (2000-2010) and MODIS 
Fig. 2. Mean meteorological forcing for the years 20002010 (11 yr): (a) wind velocity, (b) dewpoint temperature $\left(T_{\text {dew }}\right),(\mathrm{c})$ solar irradiance as downward longwave radiation flux (DLRF)
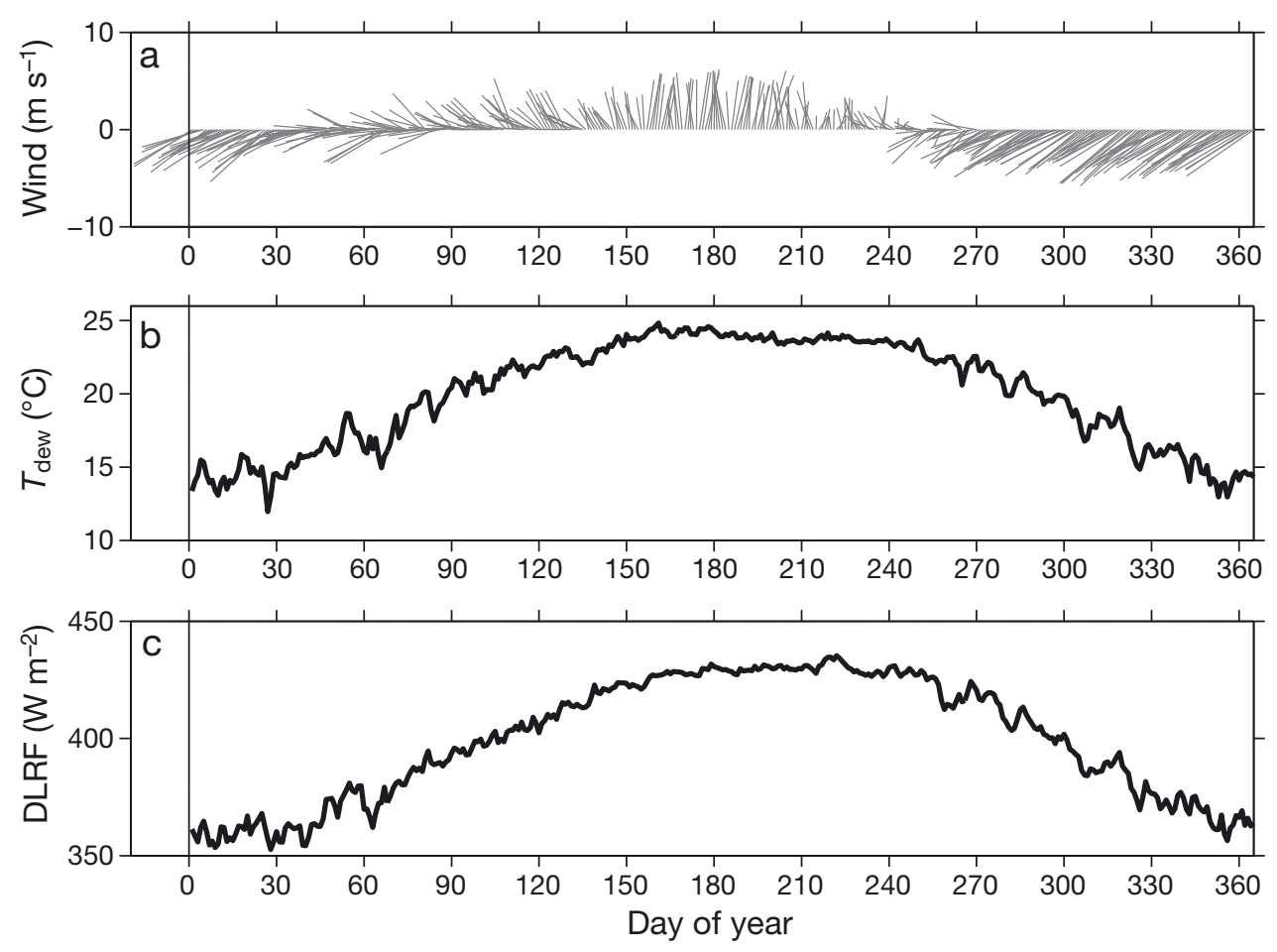

(July 2002 to 2010) surface chlorophyll concentrations from http://gdata1.sci.gsfc.nasa.gov were used and averaged between July 2002 and 2010 because of gaps in both data sets. The satellite data were averaged for the entire central Beibu Gulf region as well.

\section{RESULTS}

All model simulations for the years 2000 to 2010 started at the same initial conditions for the physical and biological module (Table 1). The only differences were in the meteorological forcing and in the initial homogeneous temperature which was taken from satellite SST for the previous year on 31 December (Table 2). A comparison of a 3 yr run using meteorological data from 2009 shows a similar vertical temperature distribution for each year, indicating stability of the numerical scheme. Despite that, an initial leg of 1 yr was introduced to allow a better adaptation of the biological components.

\section{Mean annual cycle}

In order to investigate the effect of the meteorological forcing, a mean annual cycle was modeled using the mean meteorological forcing calculated as the average over the years 2000 to 2010 (Figs. 2 \& 3). The analysis of the model results focuses on the annual cycle of physical factors, e.g. vertical temperature distribution, mixed layer depth (MLD, depth where a difference of $0.5^{\circ} \mathrm{C}$ between SST and temperature at the depth is reached), euphotic depth (1\% of the surface PAR), and biological properties, e.g. chlorophyll distribution representing primary production. The mean modeled temperature distribution for 2000 to 2010 for the entire water column down to the mean depth of $63 \mathrm{~m}$ for the central Beibu Gulf shows surface heating in summer with an associated stratification and a winter deep mixing (Fig. 3a). The stratification establishes on average in spring around Day 38 and exists until the end of November (Day 330; Fig. 3a,b). The beginning of stratification is defined as the first day in spring when surface and bottom temperatures are no longer equal, whereas the end of stratification is defined as the first day in autumn when both temperatures are equal again (Fig. 3b). During summer, the MLD persists on average at about $18 \mathrm{~m}$ depth and shows a deepening during winter (January and December) due to strong vertical mixing (Fig. 3a).

To validate the model predictions, simulated mean daily SST was compared to satellite-derived SST, which was averaged over the $11 \mathrm{yr}$ period (20002010) and in situ data (Fig. 3b). The model correctly simulated the annual cycle of temperature rising during spring and summer and its decreasing in autumn and winter due to reduced solar irradiance (Fig. 3b). Modeled and satellite-derived SST agree well during 

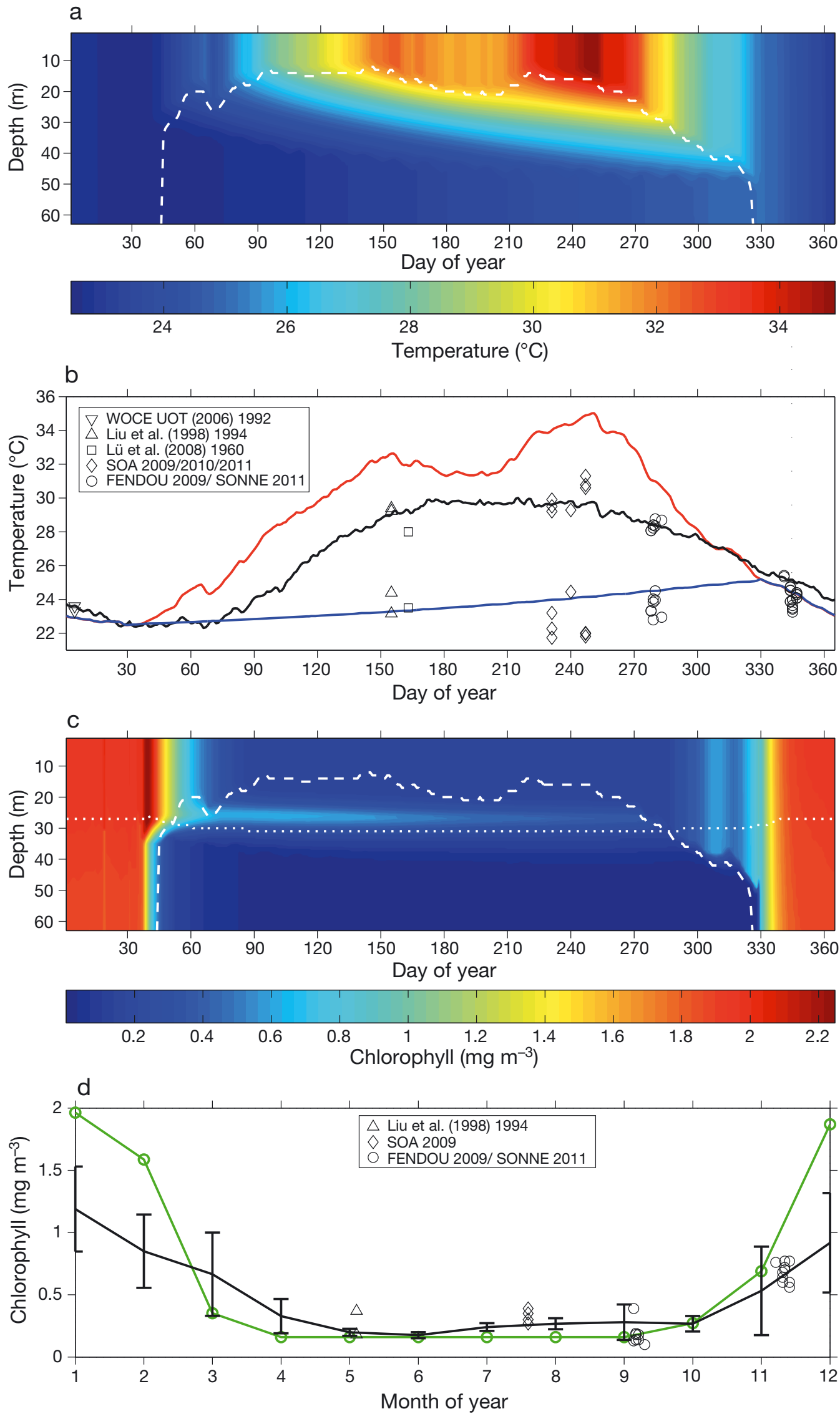
Fig. 3. Simulated mean annual cycle using mean meteorological forcing for the years 2000-2010 (11 yr) in the central Beibu Gulf. (a) Temperature distribution over the entire water column. White dashed line indicates the calculated mixed layer depth (MLD). (b) Simulated daily mean sea surface temperature (SST) (red line) in comparison to remotely measured SST (black line) averaged over the $11 \mathrm{yr}$ and in situ observations (black symbols). Blue line represents the modeled daily mean bottom temperature and the respective observations (black symbols). (c) Chlorophyll distribution over the entire water column. White dashed line indicates the calculated MLD; white dotted line indicates the euphotic depth $(1 \%$ of surface photosynthetically active radiation, PAR). (d) Simulated monthly mean sea surface chlorophyll concentrations (green line) in comparison to satellite-derived monthly mean $( \pm \mathrm{SD})$ surface chlorophyll concentrations (black line)

winter but deviate from each other during summer. The model overestimated the SST by up to $5.3^{\circ} \mathrm{C}$ in late summer. In winter, the modeled SST was slightly lower than the remotely measured SST by up to $1.1^{\circ} \mathrm{C}$. Higher temperatures during summer, especially in late summer, may result from the functional principle of the 1D model, as it is always the same water body that is heated. Lateral transport as well as a cloud cover factor are not taken into account by the model. In the mean run, wind peaks, which are normally responsible for a surface temperature cooling by mixing processes, were smoothed due to averaging, which resulted in higher surface temperatures as well. As a result, the higher dewpoint temperature and solar radiation in summer led to an increasing SST. Using mean solar irradiance, mean dewpoint temperature, but realistic wind from 2009 reduced the temperature difference between modeled and remotely measured SST in the period of highest variation, caused by highest typhoon activity, in late summer and autumn between Days 207 and 287 by

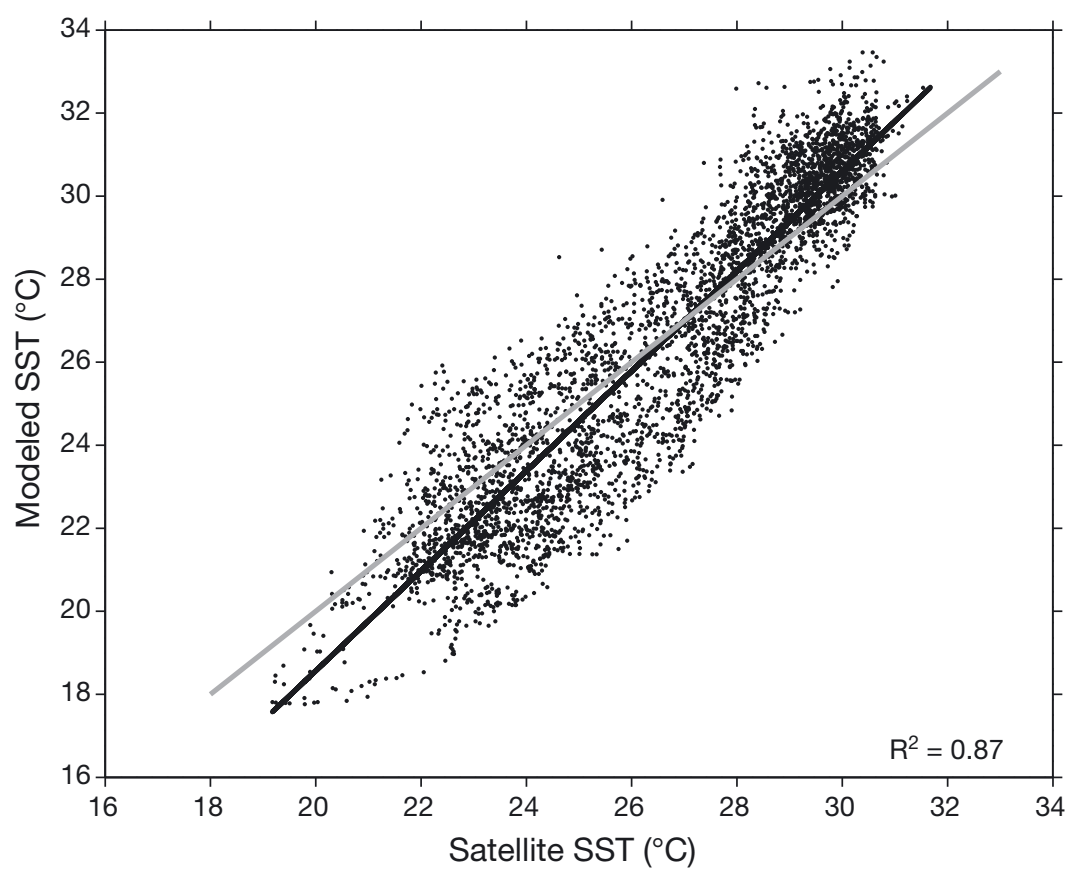

Fig. 4. Correlation between model and satellite data of all daily sea surface temperatures (SST) for the years 2000-2010. Grey line indicates the regression line with a slope of 1 up to $5.5^{\circ} \mathrm{C}$. The strong winds in this period decreased SST on average $( \pm \mathrm{SD})$ by $2.4 \pm 1^{\circ} \mathrm{C}$. Observed winter surface and bottom temperature data from the SONNE cruise and the WOCE UOT 2006 at stations within the central Beibu Gulf corroborate the model results (Fig. 3b). Also the bottom temperature data from the FENDOU 5 cruise as well as published bottom temperatures of Liu et al. (1998) and Lü et al. (2008) agree well with the model results (Fig. 3b). In summer and autumn, the in situ SST values corroborate the satellite data but not the SST of the mean year. The modeled SSTs were remarkably consistent with the remotely measured SSTs over the $11 \mathrm{yr}$ period studied. The model captured $87 \%$ of the observed variance in daily surface temperatures (Fig. 4). In winter, the modeled SSTs were slightly too low, in summer, they were slightly too high.

The modeled chlorophyll distribution shows an annual cycle with a productive season during wintertime due to the deep mixing and the formation of a DCM during summer because of the strong stratification and the nutrient depletion in the surface water layer (Fig. 3c). The DCM establishes in March when the MLD reaches $20 \mathrm{~m}$ depth and the stratification begins to develop (Fig. 3c). During summer, the DCM is located at around $26 \mathrm{~m}$ depth, somewhat shallower than the euphotic depth $(31 \mathrm{~m})$. Due to the strong vertical mixing during January and December, the phytoplankton bloom signal is transported down to the bottom below the euphotic depth which is permanently located in around 25 to $31 \mathrm{~m}$ depth (Fig. 3c). During summer, the monthly mean surface chlorophyll concentrations of about 0.1 to $0.2 \mathrm{mg}$ $\mathrm{m}^{-3}$ are captured very well by the model compared to the satellitederived concentrations averaged for the $11 \mathrm{yr}$ period and in situ measurements (Fig. 3d). The decrease of surface chlorophyll concentration in spring (February and March) and the 
increase in autumn and winter (October to December) are also well modeled but with differences of up to $0.8 \mathrm{mg} \mathrm{m}^{-3}$. In January and February as well as November and December, modeled chlorophyll concentrations were higher than those measured by satellites. On the other hand, slightly lower concentrations were modeled for March and April as well as July to September. The standard deviations represent the interannual variability of satellite monthly surface chlorophyll concentrations (Fig. 3d). From January to March and from November to December, highest standard deviations were calculated for the remotely measured chlorophyll concentrations, indicating that highest interannual variability occurs during winter.

Vertical depth profiles of temperature, chlorophyll, and DIN from different cruises during summer/ autumn corroborate the model results averaged over the summer stratification period with regard to the depth of the thermocline, the depth of the DCM, and the DIN distribution (see Figs. S2 \& S3 in the supplement).

\section{Annual cycle 2009}

In 2009, a weak stratification established at the beginning of February (Day 31) and continued developing to a fully stratified water column in spring until autumn (around Days 102 to 274; Fig. 5a). Correspondingly, the MLD reached the bottom during the winter season and became shallower in February when weak stratification occurred (Fig. 5a). During spring and summer, the MLD persisted on average at about $20 \mathrm{~m}$ depth, followed by the seasonal deepening starting at the end of September due to strong wind events and culminating in a fully mixed water column during winter.

Modeled and satellite-derived SSTs were consistent from Day 35 (February) to Day 144 (May; Fig. 5b). From that day on, the modeled SST showed slightly higher values until Day 293 (October) and lower values than those remotely measured from October to December (Days 294-365). Nevertheless, the annual mean deviation of SST reached only $-0.08^{\circ} \mathrm{C}$. The highest temperature of $32.6^{\circ} \mathrm{C}$ was modeled in September on Day 242 in comparison to the remotely measured maximum temperature of $31.7^{\circ} \mathrm{C}$ on the same day. The lowest temperature of $20.8^{\circ} \mathrm{C}$ was modeled during winter on Day 28 (January), while $21.3^{\circ} \mathrm{C}$ was measured on Day 29. Around Day 265 (September), a sudden temperature decrease of about $4.6^{\circ} \mathrm{C}$ took place within $10 \mathrm{~d}$, induced by a typhoon which passed the study area. After that, the water column was well mixed down to $44 \mathrm{~m}$ depth for around $7 \mathrm{~d}$ (Days 271-277; Fig. 5a). The water column then stratified again for a short period of around 2 wk (Days 276-291) and transitioned slowly to winter conditions. The bottom temperature showed a persistent warming from Day 26 (January) at $20.9^{\circ} \mathrm{C}$ to Day 321 (November) at $24.2^{\circ} \mathrm{C}$ (Fig. 5b). From the end of November, the bottom water temperature decreased again due to the winter mixing of the entire water column and reduced solar radiation as well as decreased dewpoint temperature during this time of the year. The observed surface and bottom temperature data from the FENDOU 5 (2009) cruise and received from SOA at the stations within the central Beibu Gulf corroborate the model results (Fig. 5b).

After the MLD reached its shallowest depth (around $3 \mathrm{~m}$ ) and the stratification was fully developed in April, the DCM became established (Fig. 5c). The summerly DCM was located at around $27 \mathrm{~m}$ depth, again shallower than the euphotic depth $(30 \mathrm{~m})$. The phytoplankton bloom in January with $1.9 \mathrm{mg} \mathrm{chl} \mathrm{m} \mathrm{m}^{-3}$ and the low concentrations of about

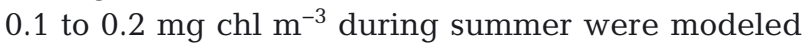
quite well (Fig. 5d). In general, the surface chlorophyll decrease in spring (February and March) and increase in autumn and winter (October to December) were well captured with differences of up to $0.9 \mathrm{mg} \mathrm{m}^{-3}$. During winter, the model results showed higher concentrations than remotely measured (Fig. 5d). The standard deviations (indicated by the green and black bars in Fig. 5d) indicate the temporal (and for the satellite data also spatial) variability of monthly mean surface chlorophyll concentrations

Fig. 5. Simulated annual cycle for 2009 in the central Beibu Gulf. (a) Temperature distribution over the entire water column. White dashed line indicates the calculated mixed layer depth (MLD). (b) Simulated daily mean sea surface temperature (SST; red line) in comparison to remotely measured SST (black line) and observations (black symbols). Blue line represents the modeled daily mean bottom temperature and the respective observations (black symbols). (c) Chlorophyll distribution over the entire water column. White dashed line indicates the calculated MLD; white dotted line indicates the euphotic depth (1\% of surface photosynthetically active radiation, PAR). (d) Simulated monthly mean $( \pm \mathrm{SD})$ sea surface chlorophyll concentrations (green line) in comparison to satellite-derived monthly mean surface chlorophyll concentrations (black line). Black circles indicate observations during the FENDOU 5 cruise; black diamonds are observations provided by the State Oceanic Administration in 2009. Error bars represent both the spatial and temporal variability of the data sets 

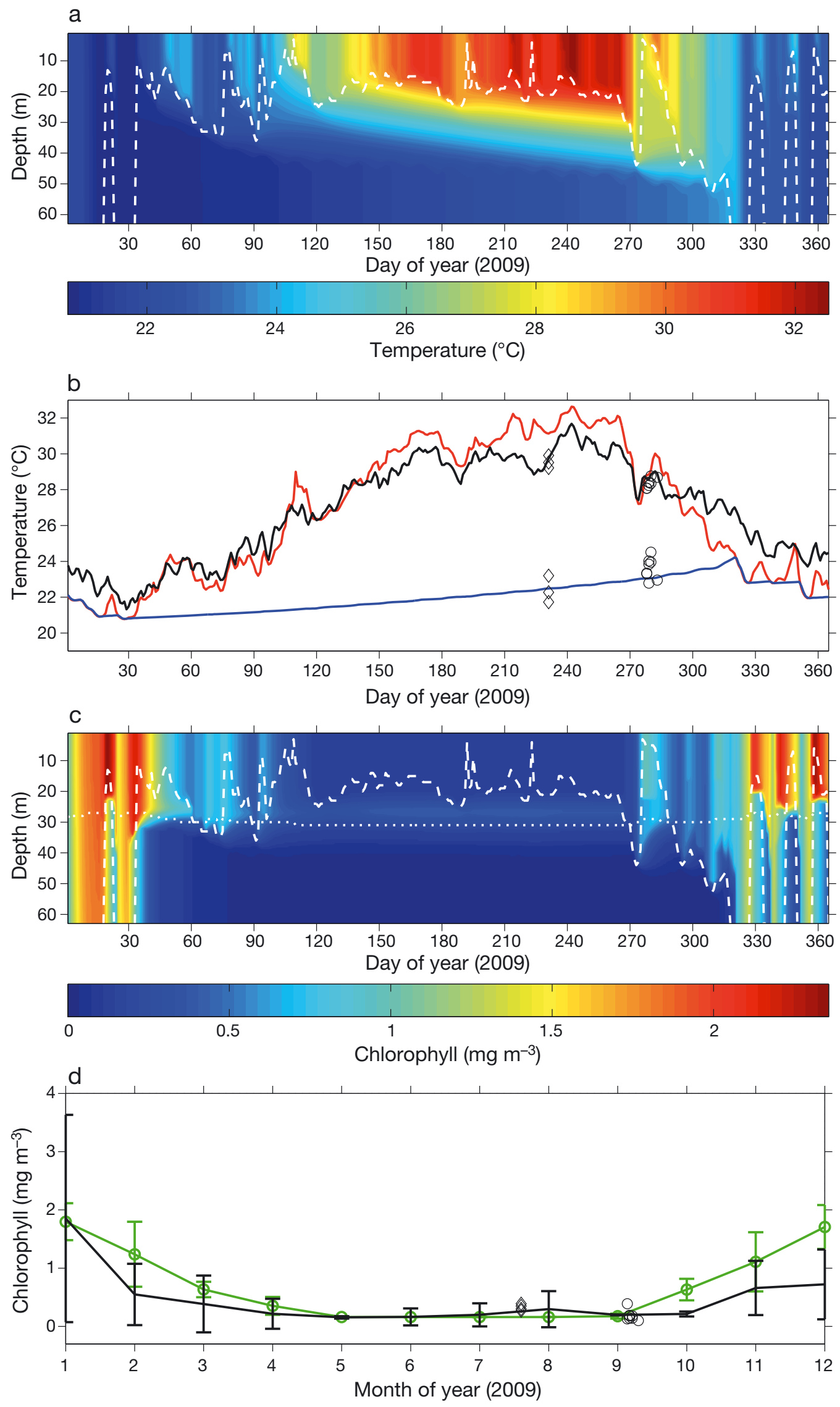

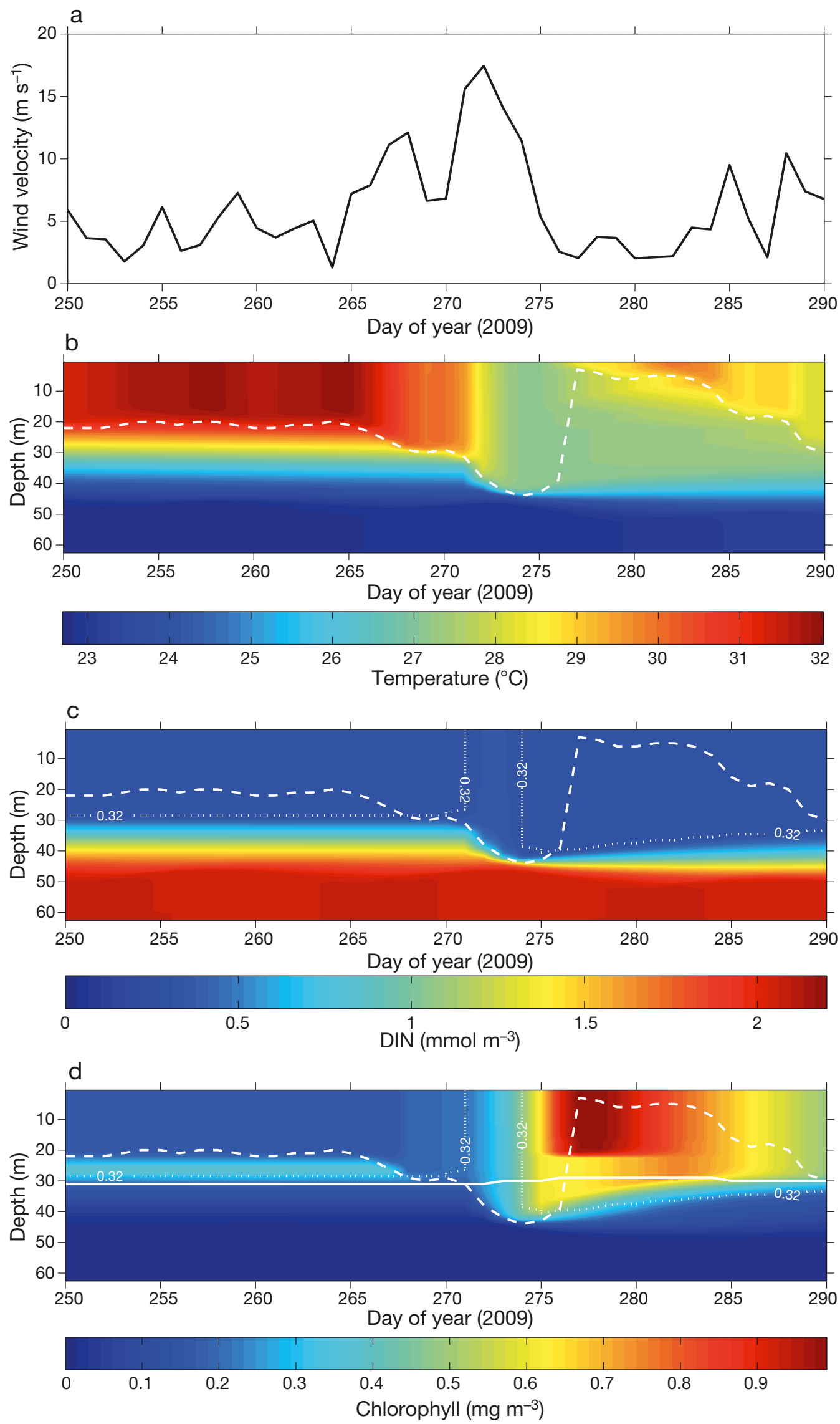

Fig. 6. September/October (Days 250-290) of 2009 showing the effect of a typhoon passing throughout the region based on (a) absolute wind velocity, (b) vertical temperature distribution, (c) vertical distribution of dissolved inorganic nitrogen (DIN), and (d) vertical chlorophyll distribution. White dashed line is the mixed layer depth (MLD) (bd); white dotted lines indicate the limiting nitrate concentration of $0.32 \mathrm{mmol} \mathrm{m}^{-3}(\mathrm{c}, \mathrm{d})$; white solid line in (d) is the euphotic depth 


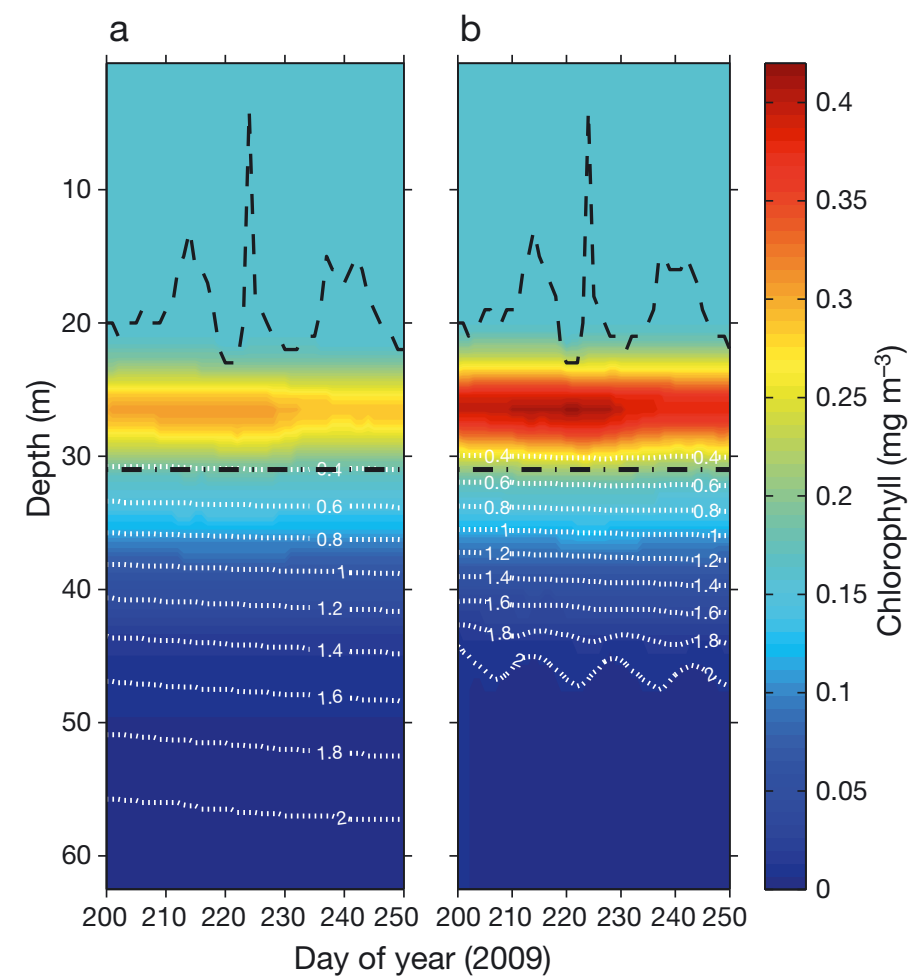

(Table S1 in the supplement). Highest variability occurred during winter and spring (between January and April as well as November and December). The measurements and the overlapping standard deviations point to a good agreement between the modeled and the remotely measured monthly mean surface chlorophyll concentrations.

\section{Effects of strong wind events}

The wind forcing at the surface is demonstrated in Fig. 6a for a time period of $40 \mathrm{~d}$, including the passing of Typhoon Ketsana (25 to 30 September 2009, Days 268-273) with maximum wind speeds of up to $17.5 \mathrm{~m}$ $\mathrm{s}^{-1}$ in the central Beibu Gulf around Day 272. Stratification was very strong during summer prior to the typhoon crossing, and the MLD only reached down to $20 \mathrm{~m}$ depth (Fig. 6b). During the typhoon (Day 272), the temperature of the surface layer decreased rapidly from around 32 to $27^{\circ} \mathrm{C}$, the thermocline deepened and destabilized, and the MLD reached $44 \mathrm{~m}$ (Fig. 6b). As a consequence, between Days 271 and 274, the nutrient concentration in the surface waters exceeded $0.32 \mathrm{mmol}^{\mathrm{DIN} \mathrm{m}} \mathrm{m}^{-3}$, the defined limiting nitrate concentration or nutricline (Fig. 6c). This in turn led to enhanced primary production in the surface layer above the euphotic depth, which was visible with a lag of about $2 \mathrm{~d}$ (Fig. 6d). The chlorophyll concentration increased from values of

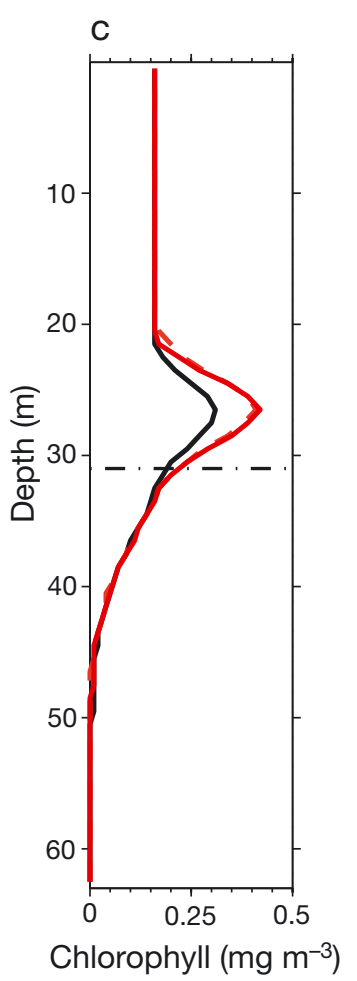

Fig. 7. Simulated $50 \mathrm{~d}$ section of daily mean vertical chlorophyll distribution and dissolved inorganic nitrogen (DIN) isolines for model runs (a) without and (b) with tidal forcing in the year 2009. Black dashed line is the mixed layer depth (MLD); dash-dotted line is the euphotic depth. (c) Chlorophyll profiles on 1 d for a model run without tidal forcing (black solid line; Day 220), for a neap tide (red solid line; Day 220), and for a spring tide (red dashed line; Day 212)

around 0.16 to $1 \mathrm{mg} \mathrm{m}^{-3}$ on Day 278 at the surface. The nutrient concentration reached its maximum $\left(0.35 \mathrm{mmol} \mathrm{m}^{-3}\right)$ on the same day (272) on which the wind reached its maximum velocity, whereas maximum chlorophyll concentration within the upper $20 \mathrm{~m}$ depth was reached $5 \mathrm{~d}$ (Days 277-278) later.

\section{Effects of tides}

Fig. 7 shows the effect of tidal forcing on the DCM within a 50 d period from July to September 2009. The resulting DCM from a model run with tides (Fig. 7b) is more developed than the DCM of a model run without tides $\left(\mathrm{M}_{2}\right.$ and $\mathrm{S}_{2}$ tidal amplitudes set to 0 , Fig. 7a). Maximum chlorophyll concentrations for the model run without tidal forcing reach $0.31 \mathrm{mg} \mathrm{m}^{-3}$ at around $26.5 \mathrm{~m}$ depth in comparison to $0.42 \mathrm{mg} \mathrm{m}^{-3}$ for the model run with tides at similar depth. This is an increase of around $36 \%$. Besides the higher concentrations, the tidally forced DCM is also slightly broader with a thickness (determined as the part of the chlorophyll depth profiles showing higher values than surface background chlorophyll concentration of $0.16 \mathrm{mg} \mathrm{m}^{-3}$, Fig. $7 \mathrm{c}$ ) of around $12 \mathrm{~m}$ compared to $9 \mathrm{~m}$ for the run without tides (Fig. $7 \mathrm{c}$ ), which is an increase of around $33 \%$. Due to the maximum tidal forcing during spring tide, the modeled DCM (Fig. 8c) is slightly shifted towards the surface by around $1 \mathrm{~m}$ at the upper boundary of the DCM. Fur- 

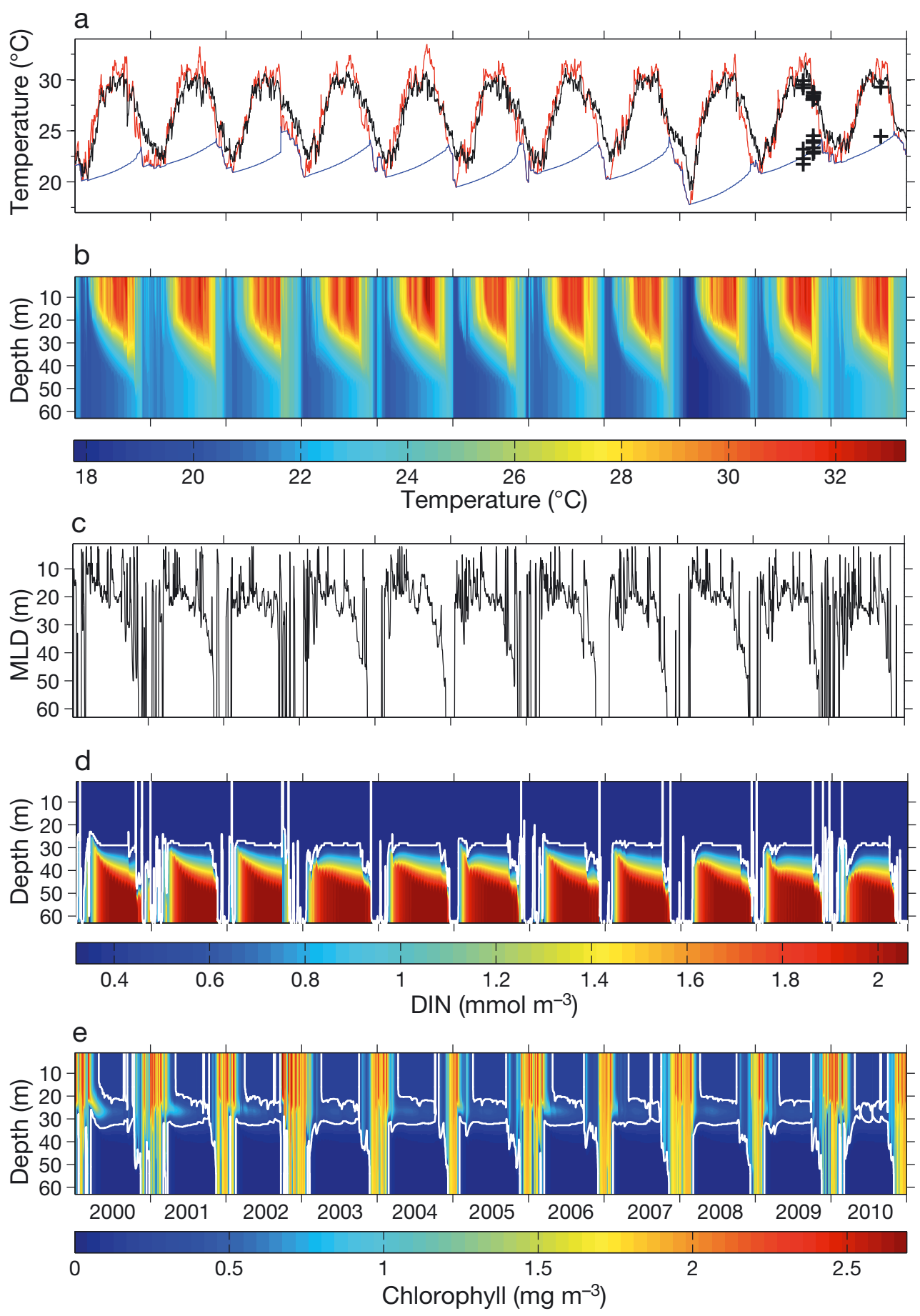

Fig. 8. Interannual comparison of the years 2000 to 2010. (a) Simulated daily mean surface (red line) and bottom temperature (blue line), and remotely measured SST (black line). Crosses indicate measurements during the FENDOU 5 cruise and cruises conducted by the State Oceanic Administration (August 2009 and 2010). (b) Daily mean temperature distribution over the entire water column. (c) Calculated daily mixed layer depth (MLD, m). (d) Daily mean dissolved inorganic nitrogen (DIN) distribution over the entire water column. White line indicates the defined limiting nitrate concentration of $0.32 \mathrm{mmol} \mathrm{m}^{-3}$. (e) Daily mean chlorophyll distribution. White lines emphasize the deep chlorophyll maximum

thermore, during spring, the rate of turbulent dissipation at the base of the thermocline increases and leads to an eroding of the stratification and hence to nutrient fluxes into the water layer above the thermocline (e.g. Sharples et al. 2001). The differences in thickness and strength of the DCM are a result of higher nutrient supply within the euphotic zone (Fig. 7a,b) and utilization of DIN by the phytoplankton due to the optimal living conditions within this layer. The tidally induced turbulence pushes the DIN isolines towards the surface. The $2.0 \mathrm{mmol} \mathrm{m} \mathrm{m}^{-3}$ isoline is located on average at about $56 \mathrm{~m}$ depth in the model run without tides but at about $45 \mathrm{~m}$ during a spring tide. As the tides in the central Beibu Gulf are weak, this effect deflates relatively fast towards the surface, which causes only $1 \mathrm{~m}$ difference in the position of the $0.4 \mathrm{mmol} \mathrm{DIN} \mathrm{m}^{-3}$ isoline. Despite this weak elevation of the nutrient-richer water layers into the thermocline, primary production within the DCM is enhanced by one-third. 


\section{Interannual variability}

As is typical for the Beibu Gulf region, the absolute wind shows lower velocities during summer when the southwest monsoon is predominant and highest velocities in winter during the northeast monsoon in the time period between 2000 and 2010 (Fig. S1a). Wind peaks during late summer and autumn (August to November) indicate strong wind events, such as tropical storms or typhoons. The downward longwave radiation flux (DLRF, $\mathrm{W} \mathrm{m}^{-2}$ ) displays the typical annual cycle with high insolation in summer (Fig. S1b). In winter, the irradiance is lower but, typical for the region, still high with values between 300 and $400 \mathrm{~W} \mathrm{~m}^{-2}$.

Maximum and minimum wind forcing in each year are mirrored by the temperature distribution (Fig. 8a,b) and the MLD (Fig. 8c). Longer periods of low wind speeds, e.g. in summer 2001 (Days 224239), 2004 (Days 218-239), 2007 (Days 227-233), and 2009 (Days 233-243) lead to an increase of temperature in the surface water layer and a shallowing of the MLD, in 2004 for instance from 27 to $3 \mathrm{~m}$ in depth and in 2007 from 30 to $2 \mathrm{~m}$. On the other hand, strong wind events in late summer and autumn, e.g. in 2000 (Day 288), 2001 (Day 222), 2002 (Day 265), 2007 (Day 276), 2009 (Day 272), and 2010 (Day 277), cause a cooling of the surface water between 0.6 and $6.7^{\circ} \mathrm{C}$, depending on the strength of maximum wind (Table 3), and a deepening of the MLD, for instance from around 6 to $50 \mathrm{~m}$ in 2000, from 19 to $63 \mathrm{~m}$ in 2002, and from 20 to $44 \mathrm{~m}$ in 2009.

The start of sustained stratification and vertical mixing is indicated by the surface and bottom temperature trends when SST and bottom temperature begin to diverge in spring and converge again in autumn, respectively (Fig. 8a). Periods of mixing and/or weak stratification occur between the middle of September and the middle of March of the following year. The beginning of the main period of stratification is defined as the first day after the last day of entire vertical mixing, the end as the first day of total vertical mixing in 1 yr (Fig. 8a, Table 2). In the Beibu Gulf, the winter period is the main productive season (Hu et al. 2003, Tang et al. 2003). The termination of the thermal stratification in autumn/winter is the most important factor for the timing of nutrient supply from the bottom waters (Fig. 8d) and hence the initiation and timing of the phytoplankton bloom. On average, the termination of stratification takes place in November with a strong nutrient input into the surface layer in most of the years directly after the stratification breakdown indicated by shallowing of the nutricline (Fig. 8d, white line). In all years, the limiting nitrate concentration of about $0.32 \mathrm{mmol} \mathrm{m}^{-3}$ (which is equivalent to a phosphate concentration of $0.02 \mathrm{mmol} \mathrm{m}^{-3}$ necessary for phytoplankton growth) lies on average at $29 \mathrm{~m}$ depth during summer, with higher values below and a nutrient-depleted surface water body (Fig. 8d). In autumn and winter, when the mixed layer deepens, nutrient inputs from the bottom water layer into the surface layer enhance nutrient concentrations within the euphotic zone (Fig. 8d). In some years (e.g. 2001, 2004, and 2010), this nutrient input is not visible because it is directly ingested by phytoplankton in the model. In autumn 2002, a strong wind event on Day 265 (Fig. S1) terminated the stratification by September, which led to a strong nutrient input into the surface layer and hence an early phytoplankton bloom (Fig. 8d,e). In all years, a phytoplankton bloom developed between autumn and winter and persisted until spring (Fig. 8e). At the turn of the years 2000/2001, 2002/2003, 2005/ 2006, and 2007/2008, the phytoplankton bloom is well developed. By contrast, the bloom is less pronounced between 2001/2002, 2004/2005, 2006/2007, and 2008/2009 (Fig. 8e). Due to the maximum MLD (63 $\mathrm{m}$ ) during winter the signal of the bloom reaches the bottom in every year. The stratification vanishes in autumn between Days 265 and 343, but the already established phytoplankton bloom starts between Days 256 and 295 (Table 2). Strong wind events as well as the change from the weaker southwest to the stronger northeast monsoon lead to a weakening of the thermocline in autumn, to episodical nutrient supply into the surface waters and hence a phytoplankton bloom establishing already before the stratification breaks down completely. On average, a bloom persists for about 204 d, or more than 6 mo. The spring stratification starts between Days 17 and 72, whereas the phytoplankton bloom ends between Days 97 and 127 (Table 2). The shortest bloom occurred between 2004 and 2005 (172 d, Table 2). Between 2005 and 2006, the bloom lasted for the longest time (229 d, Table 2). Within this 11 yr period, the well-developed bloom between 2002 and 2003 shows the highest chlorophyll concentrations at $2.7 \mathrm{mg} \mathrm{m}^{-3}$ (Table 2). The highest annual integrated surface biomass concentration of $326 \mathrm{mg} \mathrm{m}^{-3}$ was calculated for 2002, the lowest at $218 \mathrm{mg} \mathrm{m}^{-3}$ for 2003 (Table 2).

The modeled monthly mean surface chlorophyll concentrations in almost all years are higher compared to the remotely measured concentrations (Fig. 5). On average, the modeled bloom has a $0.6 \mathrm{mg} \mathrm{m}^{-3}$ higher chlorophyll concentration than remotely measured 


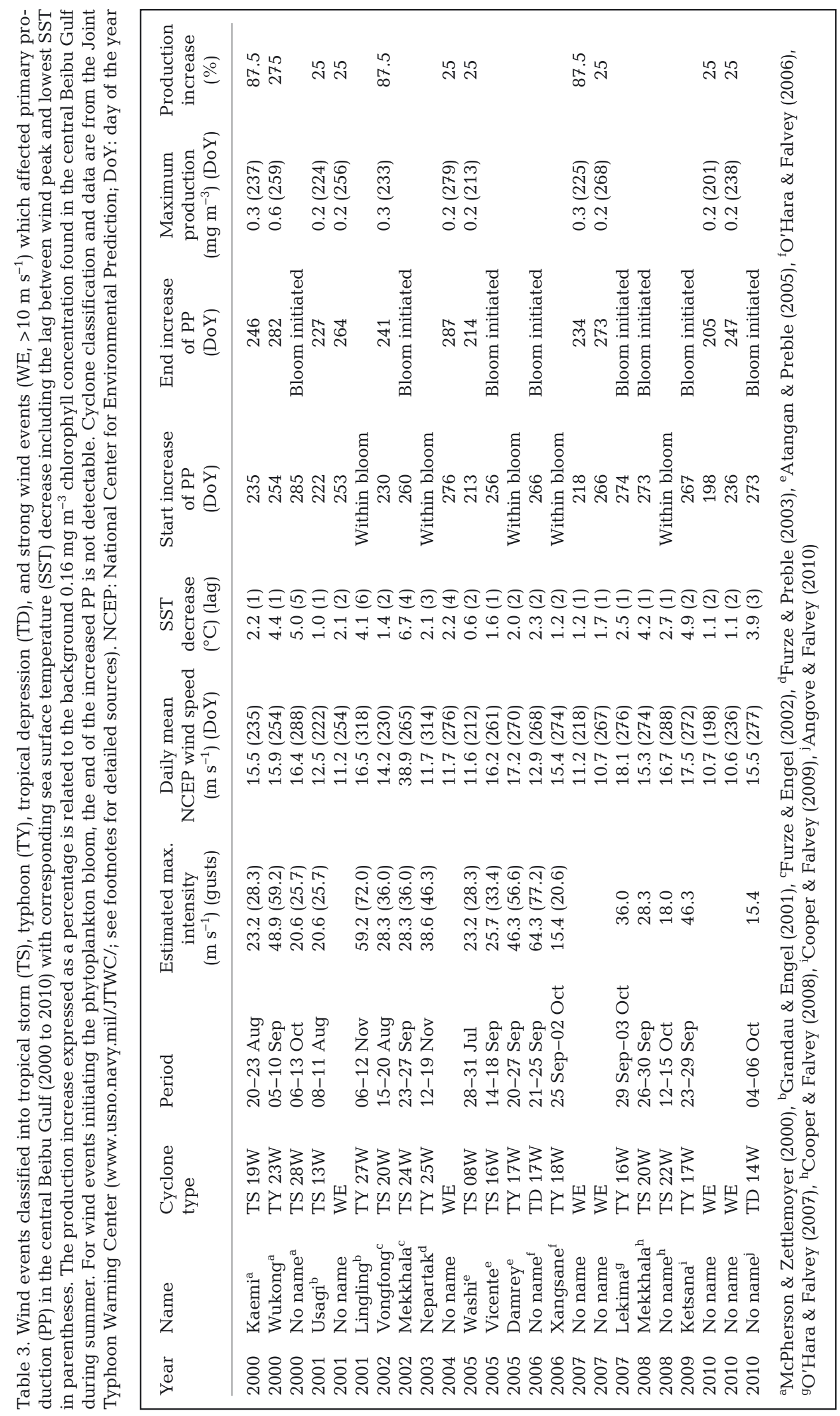




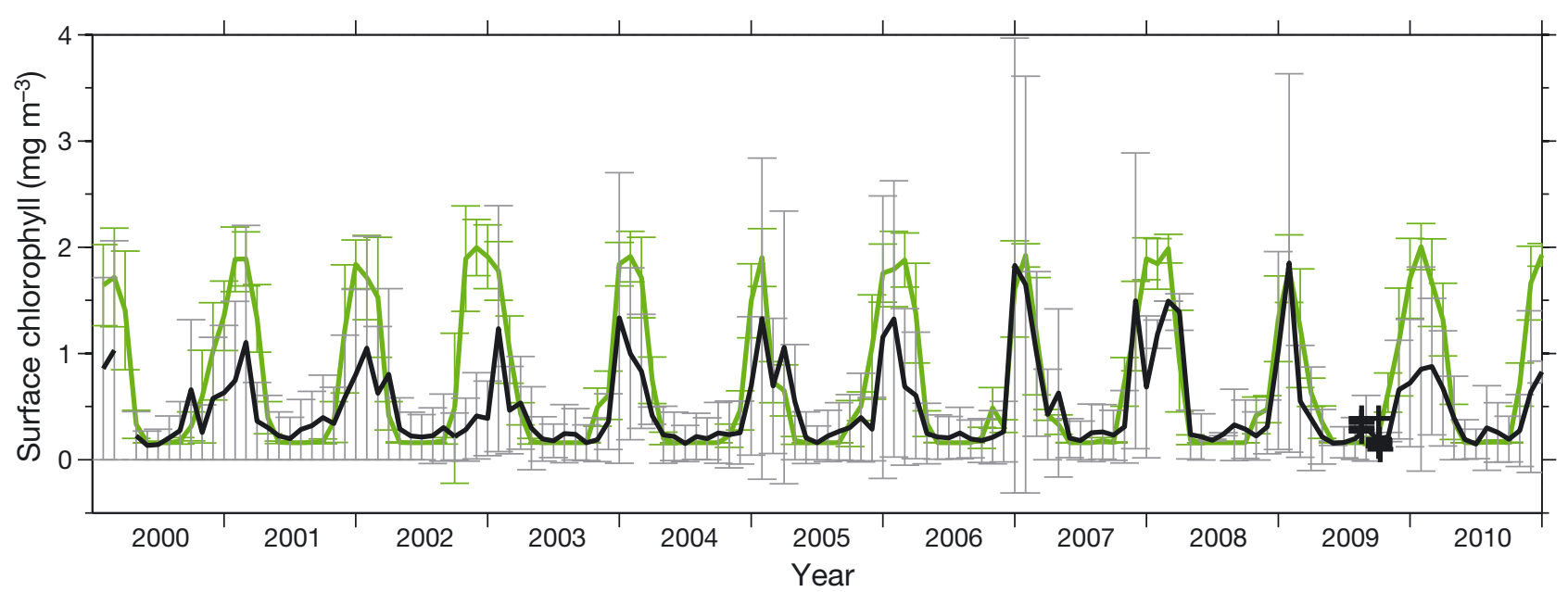

Fig. 9. Interannual variability of the modeled (green line) and remotely measured (black line) monthly mean surface chlorophyll concentrations for the time period 2000 to 2010. Grey bars indicate the spatial availability of satellite chlorophyll data for the central Beibu Gulf, and the crosses show measurements during the FENDOU 5 cruise and a cruise conducted by the State Oceanic Administration (August 2009)

and a shift of up to 2 mo between both signals can be seen, for example between 2002 and 2003 (Fig. 9). While the satellite observed blooms start in November/December and continue until April/May, the modeled blooms start between September and December and continue until January to March (Fig. 9).

In all years, a DCM was detected more or less developed between $19 \mathrm{~m}$ (e.g. in 2001) and $33 \mathrm{~m}$ (e.g. in 2004; Fig. 8e, emphasized by the white line which indicates the $0.2 \mathrm{mg} \mathrm{chl} \mathrm{m}^{-3}$ isoline). In some years, short-lived blooms prior to the main phytoplankton bloom were modeled. These blooms are associated with strong wind events in late summer and autumn (Fig. S1) for example in 2000 and 2005 to 2010 (Fig. 8e).

\section{DISCUSSION}

Considering that the model works simply with vertical exchange and does not include advective flows, its success in capturing $87 \%$ of the observed variance in daily surface temperatures indicates that surface water masses from the South China Sea or the Beibu Gulf coastal regions do not strongly affect the central Beibu Gulf. This agrees with the general cyclonic circulation pattern in the Beibu Gulf (Wu et al. 2008). Therefore, the local meteorological forcing seems to be the most important factor for the formation of the vertical water column temperature distribution. The approximately $14 \%$ over- and underestimation for summer and winter temperatures, respectively, can be explained by the structure of the 1D model itself, as it always warms up and cools down the same body of water, because lateral transports of water masses are not taken into account by the model. Another reason is the missing cloud cover correction within the model. The surface dewpoint temperature (minimum of $4.2^{\circ} \mathrm{C}$ in winter and maximum of $28.4^{\circ} \mathrm{C}$ in summer; Table 2) and the high solar irradiance (typically ranging between 297 and $449 \mathrm{~W} \mathrm{~m}^{-2}$, Table 2) result in a strong stratification during summer with SSTs of up to $33.5^{\circ} \mathrm{C}$.

Wind and its effects on water column stability seem to play the most important role for phytoplankton growth in the central Beibu Gulf. The assumption was tested using the model with only 1 changed meteorological forcing parameter (dewpoint temperature, solar irradiance, and wind velocities) for 2009 in each run. The minimum and maximum values of the respective forcing parameter were used to act throughout the year. The differences in the resulting annual mean of surface chlorophyll concentrations between the model runs forced with the minimum and maximum value of every meteorological input are $4 \%$ for solar irradiance $\left(\mathrm{min} .=305 \mathrm{~W} \mathrm{~m}^{-2}\right.$, max. $=$ $449 \mathrm{~W} \mathrm{~m}^{-2}$ ), $63 \%$ for the surface dewpoint temperature $\left(\min .=8.0^{\circ} \mathrm{C}\right.$, $\max .=27.3^{\circ} \mathrm{C}$ ), and $90 \%$ for wind velocities $\left(u_{\min .}=-0.0017 \mathrm{~m} \mathrm{~s}^{-1}, v_{\min .}=-0.041 \mathrm{~m} \mathrm{~s}^{-1}\right.$, $u_{\text {max. }}=-11.99 \mathrm{~m} \mathrm{~s}^{-1}, v_{\text {max. }}=-14.95 \mathrm{~m} \mathrm{~s}^{-1}$ ). This supports our conclusion that wind is the most important parameter for phytoplankton growth in the central Beibu Gulf. This is already known from the Arabian Sea, which is also a monsoon-influenced region (e.g. Bauer et al. 1991). Based on observations, Bauer et al. (1991) identified wind forcing as the primary factor influencing the MLD and hence pigment biomass in the monsoon season. 
As the light regime is relatively constant throughout the year, phytoplankton growth depends mainly on the availability of nutrients, which in turn is affected by the water column structure and physical forces acting upon it. Due to the strong water column stratification (see Figs. S2a \& S3a), most pronounced between February and November, the central Beibu Gulf is nutrient depleted in the upper water layer during this period (Figs. S2c \& S3c). As a result, only minimum phytoplankton growth takes place in the surface waters, and a DCM develops at around 20 to $30 \mathrm{~m}$ depth where the nutricline and euphotic zone overlap (see Fig. 6d). The depth of the DCM seems to depend on the depth of the nutricline rather than on the euphotic depth (Fig. 6d), which was described by Cullen \& Eppley (1981) for the Southern California Bight. They found the depth of the DCM at about 20 to $50 \mathrm{~m}$ correlating more with the depth of the nutricline (15-45 $\mathrm{m}, 15-6 \%$ of the surface irradiance available) than with the euphotic depth (33-66 m). For the mean modeled year, the calculated PAR at the mean depth of the DCM $(26 \mathrm{~m})$ is about $4 \%$ of the surface PAR. The link between the nutricline and the DCM results in a gradual deepening of the nutricline and the DCM within the thermocline, which was shown for the western English Channel by Sharples et al. (2001).

The mean modeled DCM is located somewhat shallower than the depth range for the DCM in the central Beibu Gulf of about 30 to $50 \mathrm{~m}$ reported by Huang et al. (2008), Wu (2008), and Bauer et al. (in press). Our own measurements and literature values (Liu et al. 1998) indicate a relatively high variability in the depth of the DCM as well as in its strength. The mean modeled DCM shows maximum chlorophyll concentrations of around $0.5 \mathrm{mg} \mathrm{m}^{-3}$ (Fig. 3c), whereas the maximum chlorophyll concentrations within the DCM vary between 0.2 and $1.1 \mathrm{mg} \mathrm{m}^{-3}$ (Fig. 8e) for the different years, and particularly for different periods within the years, which agrees well with the range of 0.6 to $1 \mathrm{mg} \mathrm{m}^{-3}$ reported by $\mathrm{Wu}$ (2008) and Bauer et al. (in press). If enough nutrients and light are available to compensate for loss processes through photosynthesis, a net phytoplankton bloom occurs when cells are trapped near the surface (Sverdrup 1953, Ward \& Waniek 2007). Despite the strong stratification during summer, the existence of a DCM implies that a complete decoupling of the surface and bottom waters does not occur (Sharples \& Tett 1994). The continuous presence of the DCM throughout the summer is caused by the variability in surface wind stress driving occasional events introducing DIN into the system (Sharples \& Tett 1994), rather than by tidally-driven turbulence as discussed later. Depending on the strength and quantity of these events, the DCM is more or less strongly developed within the different years. The DCM can disappear for periods when the time between the entrainment events is longer than the utilization time scale of DIN (Sharples \& Tett 1994); this clearly happened in autumn 2004 and summer 2010 (Fig. 8d).

Due to the strong northeast monsoon beginning in autumn, the stratification breaks down between October and December and allows the development of a phytoplankton bloom. The onset of the phytoplankton bloom around Day $273 \pm 22$ (Table 2), some $47 \mathrm{~d}$ before the disappearance of stratification on Day $320 \pm 55$, leads to the assumption that stratification is already weakened in autumn due to tides, storms, and the change of the wind system to the stronger northeast monsoon, before it finally disappears. The stronger wind-driven turbulence induced at the surface deepens the MLD (Bauer et al. 1991) and leads to nutrient input into the surface water layer through the thermocline. In turn, this allows a phytoplankton bloom to start before stratification breaks down. Differences in the strength and quantity of nutrient inputs lead to different timing and development of the phytoplankton bloom (cf. Waniek 2003). Ongoing strong winds and the further decrease in solar irradiance then enable a mixing down to the seabed and full development of the bloom. The spring stratification starts on average around Day $44 \pm 19$, whereas the phytoplankton bloom ends around Day $112 \pm 15$ (Table 2). It takes about $69 \mathrm{~d}$ until stratification is fully developed and nutrients within the surface water layer are depleted. About 2 mo after stratification occurs, phytoplankton growth is terminated, indicating a very slow onset of full stratification, probably with periodic nutrient inputs in the surface layer due to tidal forcing, a low nutrient uptake rate, slow remineralization, or a grazing pressure acting on the phytoplankton. According to Chung et al. (2012), phytoplankton blooms are terminated due to herbivore grazing rather than nutrient depletion or sedimentation. A model test with deactivated grazing showed that a strong phytoplankton bloom would persist over the entire year. Despite nutrient depletion during summer, zooplankton grazing seems to be the most important factor for termination of the phytoplankton bloom in the central Beibu Gulf. The variability in the beginning and ending of stratification and phytoplankton bloom indicates that the timing of the bloom is less variable than the timing of stratification (e.g. Sharples et al. 2006). This also supports the conclusion that wind forcing is the most 
important factor driving primary production in the central Beibu Gulf.

The differences between both developments of modeled and remotely measured monthly mean surface chlorophyll concentration could be caused by lateral transport, which is not included in the model (Fig. 9). Through currents and tide-induced lateral transport, nutrients for phytoplankton growth, or phytoplankton itself, as well as grazers may be transported to/from the central Beibu Gulf from/to other regions. This would have an effect on the surface chlorophyll concentration within the central Beibu Gulf. The standard deviations for the satellite data (Fig. 9) display the spatial variability of the remotely measured surface chlorophyll concentrations. Between 0 and 121 pixels $\mathrm{mo}^{-1}$ were recorded by SeaWiFS within the central Beibu Gulf (Table S1). During winter, satellite data for the central Beibu Gulf are sparse, probably due to a higher cloud cover caused by activity of tropical storms. The differences between the surface chlorophyll concentrations and the beginning of the phytoplankton bloom can therefore be attributed to the lack of available satellite data. The small standard deviations in the output data indicate that the model successfully simulated the surface chlorophyll concentrations for the region.

The low variability in meteorological forcing is mirrored in the model results (Table 2). Surface and bottom water temperatures as well as surface chlorophyll concentrations do not show great differences between years, and variations are the result of strong wind events. In correspondence with the strong wind events, the SST declines due to entrainment of colder, subsurface water masses into surface waters (Price 1981) by 0.6 to $6.7^{\circ} \mathrm{C}$ (Table 3), depending on wind strength, comparable to measured SST responses between -2.5 and $-9^{\circ} \mathrm{C}$ (Chang et al. 1996, Lin et al. 2003, Walker et al. 2005, Shi \& Wang 2007, Zheng $\&$ Tang 2007). The lag between the wind peak and the lowest SST is about 1 to $6 \mathrm{~d}$ (cf. Shi \& Wang 2007), depending as well on the wind intensity and the duration of strong wind influence or the transit time of the respective typhoon. Despite the pronounced summer stratification, strong wind events such as tropical storms lead to a deepening of the MLD (Price 1981, Jiang et al. 2009) and hence to a higher nutrient supply in the surface water layer resulting in a short-lived enhancement of the primary productivity or a phytoplankton bloom (e.g. Zheng \& Tang 2007). These results are supported by several studies based on satellite data or in situ measurements describing such blooms for different typhoon- or hurricaneinfluenced regions (e.g. Chang et al. 1996, Fogel et al. 1999, Shiah et al. 2000, Lin et al. 2003, Babin et al. 2004, Zheng \& Tang 2007, Chung et al. 2012, Lin 2012). Wind velocities (Fig. S1) show that typically more than 1 strong wind event influenced the central Beibu Gulf region during almost every year from 2000 to 2010 in late summer and autumn. In the $11 \mathrm{yr}$ period, 11 events were detected which initiated a small bloom prior to the highly developed bloom, statistically 1 event $\mathrm{yr}^{-1}$ (Table 3 ). On average, the estimated temporary increase in primary production induced by these strong wind events accounts for $65 \%$ with an average duration of $11 \pm 7 \mathrm{~d}$. This result corresponds well to the $11 \mathrm{~d}$ bloom duration after the crossing of Hurricane Katrina in the Gulf of Mexico in August 2005 (Shi \& Wang 2007). About 1 to $7 \mathrm{~d}$ lagged between the wind-stress peak and the modeled chlorophyll peak at the surface (Table 3), which is comparable to the 3 to $4 \mathrm{~d}$ lag postulated by Walker et al. (2005) for Hurricane Ivan, the $4 \mathrm{~d}$ lag described by Shi \& Wang (2007) for Hurricane Katrina, both in the Gulf of Mexico, and the 3 to $6 \mathrm{~d}$ lag described by Zheng \& Tang (2007) for Typhoon Damrey in the South China Sea. The modeled lag between the lowest SST and the chlorophyll peak of up to $6 \mathrm{~d}$ agrees well with the $4 \mathrm{~d}$ lag described by Zheng \& Tang (2007).

However, to what extent a typhoon will affect an oceanic region depends on the wind intensity, the transit time, and the ocean's precondition, which means how deep or shallow the nutrient-rich water body lies (Lin 2012). If any condition is unfavorable, the ocean's response will be weakened (Lin 2012). For example, the modeled Typhoon Washi enhanced the surface chlorophyll concentration in the central Beibu Gulf to up to $0.2 \mathrm{mg} \mathrm{m}^{-3}$ at a maximum wind speed of $11.6 \mathrm{~m} \mathrm{~s}^{-1}$ but enhanced the maximum surface chlorophyll concentration by up to $0.9 \mathrm{mg} \mathrm{m}^{-3}$ (around 3.8 times before the typhoon) in the SCS at wind speeds of around $18 \mathrm{~m} \mathrm{~s}^{-1}$ (Chen \& Tang 2011). The greatest effect on the chlorophyll increase was seen from the passage of Typhoon Wukong through the region in 2000 (Table 3). This storm initiated a bloom lasting $28 \mathrm{~d}$ with a maximum surface chlorophyll concentration of $0.6 \mathrm{mg} \mathrm{m}^{-3}$, an increase of $275 \%$ compared to the summer background surface chlorophyll concentration of $0.16 \mathrm{mg} \mathrm{m}^{-3}$. Along with these temporary bloom events, tropical storms can also initiate a phytoplankton proliferation, for example in 2000, 2002, and 2005 to 2010, resulting in a bloom as early as mid-September such as those in 2002 or 2005. The effect of strong wind events on surface chlorophyll concentration during the fully developed bloom is difficult to estimate. 
Contrary to our expectations, the effect of tides on primary production within the central Beibu Gulf is only moderate. This may be a result of the relatively great depth $(63 \mathrm{~m})$, the distance from shore, the associated small tidal forcing in this region, and the lateral transport initiated by tides, which is not included in the model, or a combination of these factors. The strong stratification can reduce the already weak tidal forcing, which therefore only has a minor effect on mixing in the surface water column during summer. In spite of the weak tides $\left(0.15 \mathrm{~m} \mathrm{~s}^{-1}\right.$ for amplitude of $\mathrm{M}_{2}$ tidal currents) in this region, the tidally generated turbulence increases the strength of the DCM by up to $36 \%$ and its thickness by up to $33 \%$.

According to the results of Sharples et al. (2006), a tidal current amplitude of $0.4 \mathrm{~m} \mathrm{~s}^{-1}$ can offset the influence of heating in stratifying the water column. The result of this would be a weakly stratified water column and a breakdown of stratification that occurs earlier in the year. Ultimately, due to the intense nutrient input from the deep water to the surface layer, it would strongly enhance the primary production within the surface water layer throughout the year. The rising bathymetry from south to north in the region means the shallow northern or coastal regions may be considerably more affected by tidal currents than the relatively deep central part of the gulf. In a system which is strongly influenced by tides, a constant competition between tidal turbulence in the bottom layer and wind-driven turbulence in the surface layer determine the position of the thermocline and its associated DCM (Sharples 1999). During spring tides, when the maximum currents occur, the tidal turbulence pushes the thermocline towards the sea surface, while during neap tides, with only weak currents, the wind-driven turbulence pushes the thermocline deeper in the water column (e.g. Sharples 1999). These forces cause periodic pulses of nutrients to the euphotic zone and hence higher chlorophyll concentrations within the DCM. In the central Beibu Gulf, the influence of the spring-neap tidal cycle on the elevation of the DIN isolines is only visible to a depth of $40 \mathrm{~m}$ (Fig. 7b). Hence the expected periodic pulses of higher chlorophyll concentrations within the DCM do not occur.

\section{CONCLUSIONS}

As is typical for subtropical/tropical shelf seas, the central Beibu Gulf shows an annual cycle with a strong stratification during summer and a deep mix- ing down to the seabed in winter. The physical structure of the water column is reflected in the seasonal cycle of primary production. A phytoplankton bloom develops when the wind system changes in autumn into the stronger northeast monsoon, the solar irradiance decreases, deep mixing occurs, and nutrients from bottom waters are supplied to the surface waters and therefore are available for phytoplankton. During summer, due to the strong stratification, the surface waters are nutrient depleted and therefore only low phytoplankton growth is possible. At a depth of around 20 to $30 \mathrm{~m}$, where euphotic depth and nutricline co-exist, a DCM developed in all modeled years.

The model successfully simulated the observed stratification, SST, and bottom temperature as well as the chlorophyll distribution. Differences in the SST and the monthly mean surface chlorophyll concentrations are a consequence of the absent horizontal advection and the missing cloud cover in the model and are also attributable to the lack of satellite data.

A water depth of $63 \mathrm{~m}$, the distance from shore, and associated weak tidal forcing explain the weak tidal influence in the central Beibu Gulf. However, tides lead to an enhanced nutrient supply within the euphotic zone and hence to a considerable increase in strength and thickness of the DCM.

Although the interannual variability is generally low, the timing of the stratification breakdown and the establishment of a phytoplankton bloom are variable within a timeframe of about 2.5 mo and around 1 mo in autumn/winter. Besides these features, strong wind events play an important role in the primary production within the central Beibu Gulf. Single events strongly enhance primary production during the usually low productive summer season and are able to initiate a prior phytoplankton bloom. In summary, the monsoon winds and the occasionally strong wind events are the most important forces driving primary production in the central Beibu Gulf.

Our study helps to compensate for the lack of remotely measured and in situ data for the central Beibu Gulf and hence contributes to a more comprehensive understanding of processes influencing primary production in that region.

Acknowledgements. We thank the masters, crews, and participants of the FENDOU 5 and SONNE cruises. The Guangzhou Marine Geological Survey (GMGS) is gratefully acknowledged for planning and conducting the FENDOU 5 cruise and for the good cooperation. Thanks to all colleagues involved in the sample measurements, in particular B. Fründt and R. Prien from the Leibniz Institute for Baltic Sea Research Warnemünde, Germany, 
as well as D. P. Connelly from the National Oceanography Centre, Southampton, UK, for their support and helpful comments on earlier versions of this manuscript. We also thank NCEP, SeaWiFS, MODIS, Remote Sensing Systems, South China Sea Branch of the State Oceanic Administration (PR China), and WOCE for providing their data, and 3 anonymous reviewers for their perceptive comments. This work was financially supported by the German Ministry for Education and Research (BMBF) under contract number 03F0607A and the Deutsche Forschungsgemeinschaft (DFG, WA2157/4-1).

\section{LITERATURE CITED}

Angove MD, Falvey RJ (2010) 2010 annual tropical cyclone report. US Naval Pacific Meteorology and Oceanography Center / Joint Typhoon Warning Center, Pearl Harbor, HI

Atangan JF, Preble A (2005) 2005 annual tropical cyclone report. US Naval Pacific Meteorology and Oceanography Center / Joint Typhoon Warning Center, Pearl Harbor, HI

Babin SM, Carton JA, Dickey TD, Wiggert JD (2004) Satellite evidence of hurricane-induced phytoplankton blooms in an oceanic desert. J Geophys Res 109:C03043, doi:10.1029/2003JC001938

Bauer A, Radziejewska T, Liang K, Kowalski N and others (2013) Regional differences of hydrographical and sedimentological properties in Beibu Gulf, South China Sea. $\mathrm{J}$ Coast Res (in press)

> Bauer S, Hitchcock GL, Olson DB (1991) Influence of monsoonally-forced Ekman dynamics upon surface layer depth and plankton biomass distribution in the Arabian Sea. Deep-Sea Res I 38:531-553

> Chang J, Chung CC, Gong GC (1996) Influences of cyclones on chlorophyll a concentration and Synechococcus abundance in a subtropical western Pacific coastal ecosystem. Mar Ecol Prog Ser 140:199-205

Chen CTA, Liu KK, MacDonald R (2003) Continental margin exchanges. In: Fasham MJR (ed) Ocean biogeochemistry. Springer, Berlin, p 53-97

> Chen YQ, Tang DL (2011) Remote sensing analysis of impact of typhoon on environment in the sea area south of Hainan Island. Proc Environ Sci 10:1621-1629

Chung CC, Gong GC, Hung CC (2012) Effect of Typhoon Morakot on microphytoplankton population dynamics in the subtropical Northwest Pacific. Mar Ecol Prog Ser 448: 39-49

Cooper GA, Falvey RJ (2008) 2008 annual tropical cyclone report. US Naval Pacific Meteorology and Oceanography Center / Joint Typhoon Warning Center, Pearl Harbor, HI

Cooper GA, Falvey RJ (2009) 2009 annual tropical cyclone report. US Naval Pacific Meteorology and Oceanography Center / Joint Typhoon Warning Center, Pearl Harbor, HI

Cullen JJ, Eppley RW (1981) Chlorophyll maximum layers of the Southern California Bight and possible mechanisms of their formation and maintenance. Oceanol Acta 4: 23-32

Dickey TD (1988) Recent advances and future directions in multi-disciplinary in situ oceanographic measurement systems. In: Rothschild BJ (ed) Toward a theory on biological-physical interactions in the world ocean. Kluwer Academic Publishers, Dordrecht, p 555-598

Emery WJ, Thomson RE (2001) Data analysis methods in physical oceanography, 2nd revised edn. Elsevier Science, Amsterdam

Fogel ML, Aguilar C, Cuhel R, Hollander DJ, Willey JD, Paerl HW (1999) Biological and isotopic changes in coastal waters induced by Hurricane Gordon. Limnol Oceanogr 44:1359-1369

Furze P, Engel G (2002) 2002 annual tropical cyclone report. US Naval Pacific Meteorology and Oceanography Center / Joint Typhoon Warning Center, Pearl Harbor, HI

Furze P, Preble A (2003) 2003 annual tropical cyclone report. US Naval Pacific Meteorology and Oceanography Center / Joint Typhoon Warning Center, Pearl Harbor, HI

Grandau FJ, Engel GT (2001) 2001 annual tropical cyclone report. US Naval Pacific Meteorology and Oceanography Center / Joint Typhoon Warning Center, Pearl Harbor, HI

Hansen HP, Koroleff F (1999) Determination of nutrients. In: Grasshoff K, Kremling K, Ehrhardt M (eds) Methods of seawater analysis, Vol 2. Wiley-VCH, Weinheim, p 159-228

Howard KL, Yoder JA (1997) Contribution of the subtropical oceans to global primary production. In: Liu CT (ed) Space remote sensing of subtropical oceans. Proceedings of COSPAR Colloquium on Space Remote Sensing of Subtropical Oceans (SRSSO), Vol 8. Pergamon Press, Oxford, p 157-167

$>\mathrm{Hu}$ JY, Kawamura H, Tang DL (2003) Tidal front around the Hainan Island, northwest of the South China Sea. J Geophys Res 108:3342, doi:10.1029/2003JC001883

Huang Y, Li Y, Shao H, Li YH (2008) Seasonal variations of sea surface temperature, chlorophyll a and turbidity in Beibu Gulf, MODIS imagery study. J Xiamen Univ Nat Sci 47:856-863 (in Chinese)

IOC-SCOR (Intergovernmental Oceanographic Commission, Scientific Committee on Oceanic Research) (1994) Protocols for the Joint Global Ocean Flux Study (JGOFS) core measurements. Manual and Guides 29. UNESCO, Paris

Jiang X, Zhong Z, Jiang J (2009) Upper ocean response of the South China Sea to Typhoon Krovanh (2003). Dyn Atmos Oceans 47:165-175

> Kalnay E, Kanamitsu M, Kistler R, Collins W and others (1996) The NCEP/NCAR 40-year reanalysis project. Bull Am Meteorol Soc 77:437-471

Kirk J (2011) Light and photosynthesis in aquatic ecosystems, 3rd edn. Cambridge University Press, Cambridge

Klein P, Coste B (1984) Effects of wind-stress variability on nutrient transport into the mixed layer. Deep-Sea Res I 31:21-37

Lauria ML, Purdie DA, Sharples J (1999) Contrasting phytoplankton distributions controlled by tidal turbulence in an estuary. J Mar Syst 21:189-197

Lin II (2012) Typhoon-induced phytoplankton blooms and primary productivity increase in the western North Pacific subtropical ocean. J Geophys Res 117:C03039, doi:10.1029/2011JC007626

Lin I, Liu WT, Wu CC, Wong GTF and others (2003) New evidence for enhanced ocean primary production triggered by tropical cyclone. Geophys Res Lett 30:1718, doi:10.1029/2003GL017141

> Liu KK, Chao SY, Shaw PT, Gong GC, Chen CC, Tang TY (2002) Monsoon-forced chlorophyll distribution and primary production in the South China Sea: observations and a numerical study. Deep-Sea Res I 49:1387-1412

Liu Z, Ning X, Cai Y (1998) Distribution of size-fractionated chlorophyll a and productivity of phytoplankton in the Beibu Gulf. Acta Oceanol Sin 20:50-57 (in Chinese) 
Longhurst A (1998) Ecological geography of the sea. Academic Press, San Diego, CA

Lü X, Qiao F, Wang G, Xia C, Yuan Y (2008) Upwelling off the west coast of Hainan Island in summer: its detection and mechanisms. Geophys Res Lett 35:L02604, doi:10. 1029/2007GL032440

Manh DV, Yanagi T (1997) A three-dimensional numerical model of tide and tidal current in the Gulf of Tongking. Mer (Tokyo) 35:15-22

McPherson TR, Zettlemoyer MD (2000) 2000 annual tropical cyclone report. US Naval Pacific Meteorology and Oceanography Center / Joint Typhoon Warning Center, Pearl Harbor, HI

O'Hara JF, Falvey RJ (2006) 2006 annual tropical cyclone report. US Naval Pacific Meteorology and Oceanography Center / Joint Typhoon Warning Center, Pearl Harbor, HI

O'Hara JF, Falvey RJ (2007) 2007 annual tropical cyclone report. US Naval Pacific Meteorology and Oceanography Center / Joint Typhoon Warning Center, Pearl Harbor, HI

Price JF (1981) Upper ocean response to a hurricane. J Phys Oceanogr 11:153-175

Reynolds C (2006) Ecology of phytoplankton. Cambridge University Press, Cambridge

Ridderinkhof H (1992) On the effects of variability in meteorological forcing on the vertical structure of a stratified water column. Cont Shelf Res 12:25-36

Ross ON (2004) Algal motility in variable turbulence. PhD thesis, University of Southampton

Ross ON (2006) Particles in motion: how turbulence affects plankton sedimentation from an oceanic mixed layer. Geophys Res Lett 33:L10609, doi:10.1029/2006GL026352

Ross ON, Sharples J (2007) Phytoplankton motility and the competition for nutrients in the thermocline. Mar Ecol Prog Ser 347:21-38

Ross ON, Sharples J (2008) Swimming for survival: a role of phytoplankton motility in a stratified turbulent environment. J Mar Syst 70:248-262

Sharples J (1999) Investigating the seasonal vertical structure of phytoplankton in shelf seas. Mar Models 1:3-38

Sharples J (2008) Potential impacts of the spring-neap tidal cycle on shelf sea primary production. J Plankton Res 30: 183-197

Sharples J, Tett P (1994) Modelling the effect of physical variability on the midwater chlorophyll maximum. J Mar Res 52:219-238

Sharples J, Moore M, Rippeth T, Holligan P, Hydes D, Fisher N, Simpson J (2001) Phytoplankton distribution and survival in the thermocline. Limnol Oceanogr 46:486-496

Sharples J, Ross ON, Scott BE, Greenstreet SPR, Fraser H (2006) Inter-annual variability in the timing of stratification and the spring bloom in the North-western North Sea. Cont Shelf Res 26:733-751

Shi W, Wang M (2007) Observations of a Hurricane Katrinainduced phytoplankton bloom in the Gulf of Mexico. Geophys Res Lett 34:L11607, doi:10.1029/2007GL029724

Shi M, Chen C, Xu Q, Lin H and others (2002) The role of Qiongzhou Strait in the seasonal variation of the South China Sea circulation. J Phys Oceanogr 32:103-121

Shiah FK, Chung SW, Kao SJ, Gong GC, Liu KK (2000) Biological and hydrographical responses to tropical cy-

Editorial responsibility: Graham Savidge,

Portaferry, UK clones (typhoons) in the continental shelf of the Taiwan Strait. Cont Shelf Res 20:2029-2044

Song J (2010) Biogeochemical processes of biogenic elements in China marginal seas. Springer, Hangzhou

Strady E, Pohl C, Yakushev EV, Krüger S, Hennings U (2008) PUMP-CTD-system for trace metal sampling with a high vertical resolution. A test in the Gotland Basin, Baltic Sea. Chemosphere 70:1309-1319

> Sverdrup HU (1953) On conditions for the vernal blooming of phytoplankton. ICES J Mar Sci 18:287-295

Tang DL, Kawamura H, Lee MA, Van Dien T (2003) Seasonal and spatial distribution of chlorophyll-a concentrations and water conditions in the Gulf of Tonkin, South China Sea. Remote Sens Environ 85:475-483

Tett P, Crisp D, Fogg G (1981) Modelling phytoplankton production at shelf-sea fronts. Philos Trans R Soc Lond A 302:605-615

Tett P, Edwards A, Jones K (1986) A model for the growth of shelf-sea phytoplankton in summer. Estuar Coast Shelf Sci 23:641-672

Varela RA, Cruzado A, Tintore J, Ladona EG (1992) Modelling the deep-chlorophyll maximum: a coupled physicalbiological approach. J Mar Res 50:441-463

Walker ND, Leben RR, Balasubramanian S (2005) Hurricane-forced upwelling and chlorophyll a enhancement within cold-core cyclones in the Gulf of Mexico. Geophys Res Lett 32:L18610, doi:10.1029/2005GL023716

Waniek JJ (2003) The role of physical forcing in initiation of spring blooms in the northeast Atlantic. J Mar Syst 39: $57-82$

> Waniek JJ, Holliday NP (2006) Large-scale physical controls on phytoplankton growth in the Irminger Sea. II. Model study of the physical and meteorological preconditioning. J Mar Syst 59:219-237

Wanielista M, Kersten R, Eaglin R (1997) Hydrology: water quantity and quality control. John Wiley \& Sons, New York, NY

> Ward BA, Waniek JJ (2007) Phytoplankton growth conditions during autumn and winter in the Irminger Sea, North Atlantic. Mar Ecol Prog Ser 334:47-61

Williams RG, Follows MJ (2003) Physical transport of nutrients and the maintenance of biological production. In: Fasham MJR (ed) Ocean biogeochemistry. Springer, Berlin, p 19-51

Wu Y (2008) The temporal and spatial patterns and sizefractioned structure of primary productivity in Beibu Gulf. MS thesis, Xiamen University

Wu D, Wang Y, Lin X, Yang J (2008) On the mechanism of the cyclonic circulation in the Gulf of Tonkin in the summer. J Geophys Res 113:C09029, doi:10.1029/2007 $\mathrm{JC} 004208$

> Yoder JA, McClain CR, Feldman GC, Esaias WE (1993) Annual cycles of phytoplankton chlorophyll concentrations in the global ocean: a satellite view. Global Biogeochem Cycles 7:181-193

> Zheng GM, Tang DL (2007) Offshore and nearshore chlorophyll increases induced by typhoon winds and subsequent terrestrial rainwater runoff. Mar Ecol Prog Ser 333: $61-74$

> Zu T, Gan J, Erofeeva SY (2008) Numerical study of the tide and tidal dynamics in the South China Sea. Deep-Sea Res I 55:137-154

Submitted: April 4, 2012; Accepted: September 25, 2012 Proofs received from author(s): January 13, 2013 